\section{Penindakan Propam (Profesi dan Pengamanan) Terhadap Anggota Polisi Lalu Lintas Yang Melampai Kewenangannya Dalam Menjalankan Tugas (Studi di Kepolisian Resort Kota Besar Medan)}

\section{Abstract \\ Oleh:}

\section{Khairul Nizam ${ }^{1}$}

Members of the traffic police must be firm in taking action against traffic violations, but must not deviate from the duties they carry. The deviation of behavior of the members of the Police of the Republic of Indonesia above is a violation of the discipline rules of the members of the Police of the Republic of Indonesia as regulated in Government Regulation of the Republic of Indonesia Number 2 of 2003 concerning Discipline Regulations of the members of the Police of the Republic of Indonesia.

The formulation of the problem in this thesis research is what are the factors causing the abuse of authority carried out by the traffic police at Medan City Police Resort, how is the action taken by Propam(Profession and Security) against traffic police that exceeds their authority in carrying out their duties at Medan City Police Resort, and how to deal with against traffic police who exceeded their authority in carrying out their duties at Medan City Police Resort.

The research method used is descriptive analysis that leads to empirical juridical legal research that is research conducted by examining primary data by obtaining them directly from sources or interviews and secondary data by processing data from primary legal materials, secondary legal materials and tertiary legal materials.

The result showed that the factors causing the abuse of authority by the traffic police in Medan City Police Resort were economic factors, namely the lack of income earned by a police officer that was not comparable with the high cost of leaving. The action taken byPropam(Profession and

\footnotetext{
${ }^{1}$ Mahasiswa Magister (S2) Hukum FH UISU
}

Security) against traffic police who exceeded their authority in carrying out their duties in Medan City Police Resort was to impose sanctions for disciplinary violations against members of the Indonesian Police. The handling of traffic that exceeds their authority in carrying out their duties in Medan City Police Resort, among others, by holding a discussion of cases so that a commitment is made to the decision to be taken as a member of the traffic police with restrictions so as not to occur abuse of authority, carried out for justice and the public interest.

Key-Words: Repression, Profession and Security (Propam), Beyond Authority.

\section{Abstrak}

Anggota Polantas harus bersifat tegas dalam menindak pelanggaran lalu lintas, tetapi tidak boleh bersikap menyimpang dari tugas yang diembannya.Penyimpangan perilaku anggota Polri tersebut di atas adalah merupakan pelanggaran terhadap peraturan disiplin anggota Polri sebagaimana yang diatur dalam Peraturan Pemerintah Republik Indonesia Nomor 2 Tahun 2003 tentang Peraturan Disiplin Anggota Polri.

Rumusan masalah dalam penelitian tesis ini adalah apa faktor penyebab penyalahgunaan wewenang yang dilakukan oleh polisi lalu lintas di Polrestabes Medan, bagaimana penindakan yang dilakukan Propam terhadap polisi lalu lintas yang melampaui kewenangannya dalam menjalankan tugas di Polrestabes Medan, bagaimana penanggulangan terhadap polisi lalu lintas yang melampaui kewenangannya dalam menjalankan tugas di Polrestabes Medan.

Metode penelitian yang digunakan adalah deskriftif analisis yang mengarah pada penelitian hukum yuridis empiris yakni penelitian yang dilakukan dengan cara meneliti data primer dengan memperolehnya secara langsung dari sumbernya atau wawancara dan data sekunder dengan mengolah data dari bahan hukum primer, bahan hukum sekunder dan bahan hukum tersier.

Hasil penelitian menunjukkan bahwa faktor penyebab penyalahgunaan wewenang yang dilakukan oleh polisi lalu lintas di Polrestabes Medan adalah faktor ekonomi 
Media Komunikasi dan Informasi Hukum dan Masyarakat

yaitu kurangnya penghasilan yang diperoleh seorang aparat kepolisian yang tidak sebanding dengan tingginya kebutuhan biaya hidup. Penindakan yang dilakukan Propam terhadap polisi lalu lintas yang melampaui kewenangannya dalam menjalankan tugas di Polrestabes Medan adalah dengan memberikan sanksi atas pelanggaran disiplin terhadap anggota Polri. Penanggulangan terhadap polisi lalu lintas yang melampaui kewenangannya dalam menjalankan tugas di Polrestabes Medan antara lain dengan mengadakan suatu gelar atau diskusi tentang perkara-perkara sehingga tercapainya suatu komitmen untuk keputusan yang akan diambil sebagai anggota polisi lalu lintas dengan batasan-batasan agar tidak terjadinya penyalahgunaan wewenang, dilakukan untuk keadilan dan kepentingan umum.

Kata Kunci: Penindakan, Propam, Melampaui Kewenangan

\section{PENDAHULUAN}

\section{A. Latar Belakang}

Polisi Republik Indonesia (selanjutnya disingkat Polri) merupakan salah satu profesi dalam dunia hukum. Polisi dalam menjalankan tugasnya memerlukan profesionalitas serta kerja keras. Setiap anggota Polri memiliki tugas yang diamanatkan Undang-undang Dasar 1945 yaitu dalam penegakan hukum agar tercipta kondisi yang aman, tertib, dan damai didalam masyarakat. Tugas polisi sebagaimana yang diamanatkan dalam Undang-undang Dasar 1945 di dalam pelaksanaan di lapangan harus menghadapi tantangan seperti kejahatan nasional maupun transnasional, kejahatan korupsi, masalah lalu lintas, terorisme, masalah wilayah perbatasan, dan reformasi institusi. ${ }^{2}$

Pasal 2 Undang-Undang Nomor 2 Tahun 2002 No. 2 tahun 2002 tentang Kepolisian Negara Republik Indonesia berbunyi bahwa fungsi kepolisian adalah salah

2 Rahardi Pudi, Hukum Kepolisian Kemandirian Profesionalisme dan Reformasi Polri, Laksbang Grafika, Surabaya, 2014, hlm. 15. satu fungsi pemerintahan negara di bidang pemeliharaan keamanan dan ketertiban masyarakat, penegakan hukum, perlindungan, pengayoman dan pelayanan kepada masyarakat.

Polri dalam perspektif fungsi maupun lembaga memiliki tanggung jawab untuk melindungi masyarakat dari segala bentuk ancaman kejahatan dan gangguan yang dapat menimbulkan rasa tidak aman, tidak tertib dan tidak tentram. Polri sebagai salah satu fungsi pemerintahan negara yang substansinya memuat hal di bidang pemeliharaan keamanan dan ketertiban masyarakat, penegakan hukum, pelindung, pengayom dan pelayanan kepada masyarakat yang merupakan sesuatu yang sakral karena bersifat bathin dan kekal yang berdasarkan hak asasi manusia dan Ketuhanan Yang Maha Esa. ${ }^{3}$

Pernyataan tentang tujuan Polri sangat penting artinya bagi pembentukan jati diri Polri, karena tujuan akan memberikan batasasan dan arah tentang apa yang harus dicapai melalui penyelenggaran fungsi Polri dalam keseluruhan perjuangan bangsa untuk mencapai tujuan nasional. Kejelasan tujuan Polri akan memberikan pula kejelasan visi dan misi yang diemban Polri sehingga pada gilirannya akan merupakan pedoman bagi penentuan metode pelaksanaan tugasnya secara tepat. ${ }^{4}$

Keinginan untuk melakukan perbaikan institusi kepolisian di era reformasi sudah semakin nampak yakni dengan adanya "political will" dengan memisahkan organisasi Polri dengan organisasi TNI. Hal ini membuktikan bahwa kepolisian yang mandiri,

\footnotetext{
3 Anton Tabah, Membangun Polri yang Kuat, Sumberseu Lestari, Jakarta, 2008, hlm.8.

4 Kunarto, Perilaku Organisasi Polri, Cipta Manunggal, Jakarta, 2001, hlm. 100
} 
Media Komunikasi dan Informasi Hukum dan Masyarakat

dan professional menjadi arah kebijakan pimpinan negara sebagai bagian dari reformasi secara menyeluruh. ${ }^{5}$

Kompleksitas tantangan tugas Polri pada era reformasi dalam perjalanannya selain telah memberi manfaat bagi Polri dengan berbagai kemajuan yang signifikan baik dibidang pembangunan kekuatan, pembinaan maupun operasional. Disisi lain diakui secara jujur terdapat akses negatif dari penyelenggaraan tugas pokoknya berupa penyimpangan perilaku anggota Polri seperti penyalahgunaan kekuasaan atau wewenang (abuse of power), dan melakukan perbuatan tercela lainnya yang melangggar kaidah-kaidah moral, sosial dan keagamaan. ${ }^{6}$

Polisi lalu lintas adalah unsur pelaksana yang bertugas menyelenggarakan tugas kepolisian mencakup penjagaan, pengaturan, pengawalan dan patroli, pendidikan masyarakat dan rekayasa lalu lintas, registrasi dan identifikasi pengemudi atau kendaraan bermotor, penyidikan kecelakaan lalu lintas dan penegakan hukum dalam bidang lalu lintas, guna memelihara keamanan, ketertiban dan kelancaran lalu lintas. $^{7}$

Pelayanan kepada masyarakat di bidang lalu lintas dilaksanakan juga untuk meningkatkan kualitas hidup masyarakat, dan dalam masyarakat yang modern lalu lintas merupakan faktor utama pendukung produktivitasnya, di dalam lalu lintas banyak masalah atau gangguan yang dapat menghambat dan mematikan proses produktivitas masyarakat. Seperti kecelakaan

\footnotetext{
${ }^{5}$ Ibid, hlm.32.

6 lbid, hlm.32.

7 Trie Haryani. "Kekerasan Oleh Polisi, mengapa Masih Terjadi", melalui http:///kekerasan-oleh-polisimengapa-masihlm.html, diakses pada Jumat, 30 November 2018 pukul $20 .^{00} \mathrm{Wib}$
}

lalu lintas, kemacetan maupun tindak pidana yang berkaitan dengan kendaraan bermotor. Polisi lalu lintas juga mempunyai visi dan misi yang sejalan dengan bahasan Polri dimasa depan.

Undang-Undang Nomor 2 Tahun 2002 No. 2 tahun 2002 tentang Kepolisian Negara Republik Indonesia mengatur dengan lengkap dan runtut mengenai tugas dan wewenang Polri, namun ada saja penyimpanganpenyimpangan yang dilakukan oleh Polri tersebut dalam menjalankan tugasnya. Penyimpangan perilaku oknum Polri tersebut merupakan pelanggaran terhadap peraturan disiplin anggota Polri.

Berdasarkan kajian IPW (Indonesian Police Watch) tahun 2009, setidaknya terdapat beberapa keluhan masyarakat yang ditujukan pada Polri. Beberapa keluhan itu antara lain:

1. Polisi dianggap arogan

2. Masih terjadi diskriminasi

3. Melakukan korupsi melalui berbagai pungutan liar

4. Dinilai lamban dalam bertindak

5. Tidak tegas dalam menindak pelaku kejahatan, utamanya yang melibatkan pemegang kekuasaan

6. Kurang transparan, dan

7. Terkesan militeristik. ${ }^{8}$

Hal-hal tersebut di atas seharusnya memang tidak dilakukan oleh anggota Polri, karena jika terjadi korupsi dan pungutan liar yang dilakukan oleh oknum anggota Polri akan berakibat terhadap menurunnya citra Polri di mata warga masyarakat, termasuk anggota kepolisian lalu lintas (Polantas) yang langsung berada di lapangan yang sangat dekat dengan masyarakat. Anggota Polantas harus bersifat tegas dalam menindak pelanggaran lalu lintas,

${ }^{8}$ Firman, "Diskresi Polisi dan Permasalahannya", melalui $h t t p: / / w w w$. Indonesia policewatchlm.com/, diakses pada Jumat, 30 November 2018 pukul $20 .{ }^{00} \mathrm{Wib}$. 
Media Komunikasi dan Informasi Hukum dan Masyarakat

tetapi tidak boleh bersikap menyimpang dari tugas yang diembannya. ${ }^{9}$

Penyimpangan perilaku anggota Polri tersebut di atas adalah merupakan pelanggaran terhadap peraturan disiplin anggota Polri sebagaimana yang diatur dalam Peraturan Pemerintah Republik Indonesia Nomor 2 Tahun 2003 tentang Peraturan Disiplin Anggota Polri. Penegakan hukum terhadap peraturan disiplin anggota Polri saat ini dirasakan masih jauh dari harapan dan belum mampu secara maksimal memberikan dampak positif bagi perilaku anggota Polri baik dikarenakan proses dari penegakan hukumnya maupun hasil dari penegakan hukum peraturan disiplinnya, antara lain masih terjadi perbedaan persepsi tentang pelaksanaan ketentuan hukum disiplin.

Anggota Polri yang melakukan pelanggaran disiplin, meskipun hal tersebut telah diatur baik oleh Peraturan Pemerintah Republik Indonesia Nomor 2 Tahun 2003 tentang Peraturan Disiplin Anggota Polri maupun ketentuan acara pelaksanaannya berdasarkan Keputusan KaPolri Nomor Polisi: Kep/431/IX/2004 tanggal 30 September 2004 tentang tata cara penyelesaian pelanggaran disiplin anggota Polri, serta berdasarkan Keputusan KaPolri Nomor Polisi: Kep/97/XII/2003 tanggal 31 Desember 2003 tentang organisasi dan tata kerja Propram Polri.

Upaya penegakan disiplin dan Kode Etik Kepolisian sangat dibutuhkan guna terwujudnya pelaksanaan tugas yang dibebankan dan tercapainya profesionalisme Polri. Sangat tidak mungkin penegakan hukum dapat berjalan dengan baik, apabila penegak hukumnya sendiri (Polri) tidak disiplin dan tidak profesional. Ketidakdisiplinan

dan ketidakprofesionalan Polri akan sangat berdampak dalam hal penegakan hukum atau pengungkapan kejahatan yang terjadi di masyarakat. ${ }^{10}$

Anggota Polri, yang seharusnya menjadi tulang punggung dalam penegakan supremasi hukum ternyata menjadi pelanggar hukum itu sendiri. Tindakan penyimpangan atau penyalahgunaan kekuasaan seperti yang dilakukan oleh aparat penegak hukum, harus ditindaklanjuti sesuai dengan proses hukum. Anggota Polri yang terbukti melakukan kejahatan maka akan dijerat 2 (dua) sanksi, yaitu pidana umum dan kode etik profesi Kepolisian. ${ }^{11}$ Dengan demikian dalam proses pemeriksaan, Berkas Acara Pemeriksaan (BAP) juga dibagi dua. Masing-masing pemeriksaan dilakukan oleh Reserse Kriminal (Reskrim) untuk pidana umum dan penyidik Pelayanan Pengaduan dan Penegakan Displin (P3D) untuk komisi sidang displin atau profesi.

Profesi dan Pengamanan (Propam) adalah salah satu wadah organisasi Polri berbentuk divisi yang bertanggungjawab kepada masalah pembinaan profesi dan pengamanan dilingkungan internal organisasi Polri yang disingkat Div Propam Polri sebagai salah satu unsur pelaksana staf khusus Polri di tingkat Markas Besar yang berada lansung di bawah Kapolri. ${ }^{12}$

Penegakan kode etik profesi polri secara lembaga menurut Pasal 17 Peraturan Kapolri Nomor 14 tahun 2011 tentang Kode Etik Profesi Polri Negara Republik Indonesia berada di bawah suatu lembaga yang bernama

\footnotetext{
${ }^{10}$ Rahardi Pudi, Op.Cit., hlm. 68.

11 Agus Subagyo, "Penegakan Etika Profesi dan Peraturan Disiplin Anggota Polri”, melalui https://wordpress.com, diakses pada Jumat, 30 November 2018 pukul $20 .{ }^{00} \mathrm{Wib}$

12 lbid.
} 
Media Komunikasi dan Informasi Hukum dan Masyarakat

Profesi dan Pengamanan atau Propam. Pada tingkat Mabes Polri Propam berbentuk Divisi yang bertanggung jawab pada Kapolri sementara pada tingkat Polda berbentuk Bidang yang bertanggung jawab pada Kapolda.

Berdasarkan data di Polrestabes Medan jumlah pungutan liar yang dilakukan oleh kepolisian selama tahun 2016 sampai dengan tahun 2018 sebanyak 29 kasus pelanggaran yang dilakukan oleh oknum anggota Satuan Lalu Lintas Polrestabes medan.

\section{Tabel 1}

\section{Data Pungutan Liar Oleh Anggota Polrestabes Medan Tahun 2016-2018}

\begin{tabular}{|c|c|}
\hline Tahun & Jumlah Kasus \\
\hline 2016 & 6 \\
\hline 2017 & 7 \\
\hline 2018 & 2 \\
\hline Jumlah & $\mathbf{1 5}$ \\
\hline
\end{tabular}

Sumber : Polrestabes Medan Tahun 2019.

Bentuk pelanggaran yang dilakukan oleh oknum Satlantas Polrestabes Medan adalah tertanggakap tangan oleh Tim Subbidpaminal Bidpropam Polrestabes Medan pada saat melakukan pungutan liar terhadap seorang pelanggar lalu lintas (pelanggaran Traffic Light) dan meminta uang dan tidak membuatkan surat tilang serta tanda terima terhadap pelanggar lalu lintas yang melanggar rambu-rambu jalur searah serta tidak memiliki SIM.

Bercermin dari banyaknya kasus pelanggaran kode etik yang timbul, seharusnya Propam Polri menghindarkan diri dari kesan menerapkan asas imunitas untuk melindungi sesame anggota korps dalam berbagai penyelewengan. Selama ini Polri sering dituding melindungi anggotanya yang melakukan pelanggaran kode etik karena ringannya hukuman hingga penegakan kode etik yang sedikit kurang transparan. Propam sebagai salah satu diantara unsur di dalam tubuh Polri, memiliki peran dalam membantu tegaknya kode etik kepolisian. Pada kenyataannya masih ada anggota kepolisian yang melakukan pelanggara kode etik kepolisian di lapangan.

Upaya penegakan kode etik profesi Polri sangat dibutuhkan untuk terwujudnya pelaksanaan tugas yang dibebankan pada profesionalisme POLRI. Ketidak profesionalisme akan sangat berdampak dalam hal penegakan hukum atau pengungkapan kejahatan yang terjadi di masyarakat. Seringnya diberitakan di berbagai media massa mengenai tindakan penyimpangan yang dilakukan oleh anggota Polri, misalnya banyaknya kasus pungli yang dilakukan oleh anggota oknum Polri.

\section{B. Perumusan Masalah}

Berdasarkan uraian latar belakang di atas, maka rumusan masalah pada penelitian ini adalah:

1. Apa faktor penyebab penyalahgunaan wewenang yang dilakukan oleh polisi lalu lintas di Polrestabes Medan?

2. Bagaimana penindakan yang dilakukan Propam terhadap polisi lalu lintas yang melampaui kewenangannya dalam menjalankan tugas di Polrestabes Medan?

\section{Tujuan Penelitian}

Adapun tujuan penelitian ini adalah sebagai berikut:

1. Untuk mengetahui faktor penyebab penyalahgunaan wewenang yang 
Media Komunikasi dan Informasi Hukum dan Masyarakat

dilakukan oleh polisi lalu lintas di Polrestabes Medan.

2. Untuk mengetahui penindakan yang dilakukan Propam terhadap polisi lalu lintas yang melampaui kewenangannya dalam menjalankan tugas di Polrestabes Medan.

3. Untuk mengetahui penanggulangan terhadap polisi lalu lintas yang melampaui kewenangannya dalam menjalankan tugas di Polrestabes Medan.

\section{Kegunaan/Manfaat Penelitian}

Kegunaan/manfaat penelitian dalam penulisan tesis ini adalah sebagai berikut:

1. Secara teoritis, penelitian ini dapat menjadi sumbangan ilmu pengetahuan terutama dibidang hukum perdata, yang nantinya dapat dijadikan sebagai sumber bacaan ataupun daftar pustaka bagi pengembangan ilmu hukum khususnya mengenai penindakan Propam terhadap anggota Polisi lalu lintas yang melewati kewenangannya dalam menjalankan tugas.

2. Secara praktis, penelitian ini dapat bermanfaat bagi para pihak baik bagi kepentingan negara, bangsa, masyarakat yang membutuhkannya secara umum terutama bagi mahasiswa Fakultas Hukum untuk dijadikannya sebagai acuan dalam melihat perkembangan yang terjadi di lapangan yang berkenaan dengan penindakan Propam terhadap anggota Polisi lalu lintas yang melewati kewenangannya dalam menjalankan tugas.

\section{E. Keaslian Penelitian}

Berdasarkan pemeriksaan yang telah dilakukan oleh peneliti di perpustakaan Universitas Islam Sumatera Utara diketahui bahwa penelitian tentang "Penindakan Propam (Profesi dan Pengamanan) Terhadap Anggota Polisi Lalu Lintas Yang Melampai Kewenangannya Dalam Menjalankan Tugas (Studi Kasus di Kepolisian Resort Kota Besar Medan)" belum pernah dilakukan dalam pendekatan dan perumusan masalah yang sama, walaupun ada beberapa topik penelitian tentang penindakan propam (profesi dan pengamanan) terhadap anggota polisi lalu lintas yang melampai kewenangannya tapi jelas berbeda yaitu :

1. Siharma Hasiholan Dominicus Rajagukguk (Prog. Pasca Magister Hk. Litigasi Universitas Atma Jaya Yogyakarta) dengan judul tesis : Peran Profesi Dan Pengamanan (Propam) Polda Dalam Penegakan Kode Etik Profesi Kepolisian Di DIY. Permasalahan dalam tesis tersebut adalah :

a. Bagaimana upaya Profesi Pengamanan (Propam) Polda DIY dalam penegakan kode etik profesi Polri di DIY?

b. Apa kendala yang dihadapi Profesi Pengamanan (Propam) Polda DIY dalam penegakan kode etik profesi Polri di DIY?

c. Bagaimana upaya Profesi Pengamanan (Propam) Polda DIY dalam mengatasi kendala dalam penegakan kode etik profesi Polri ?

2. Anugrah Ryandra Fahlevi (Prog. Pasca Magister Ilmu Hukum) dengan judul tesis : Penyelesaian Pelanggaran Kode Etik Profesi Bagi Anggota Kepolisian Yang 
Media Komunikasi dan Informasi Hukum dan Masyarakat

Melakukan Tindak Pidana. Permasalahan dalam tesis tersebut adalah :

a. Bagaimana

bentuk-bentuk pelanggaran kode etik POLRI yang termasuk tindak pidana?

b. Bagaimana proses pemeriksaan terhadap pelanggaran kode etik profesi Polri terhadap anggota POLRI yang melakukan tindak pidana?

c. Bagaimana penyelesaian pelanggaran kode etik profesi bagi anggota kepolisian yang melakukan tindak pidana?

Penelitian ini adalah asli karena sesuai dengan asas-asas keilmuan yaitu jujur, rasional, obyektif dan terbuka. Sehingga penelitian ini dapat dipertanggungjawabkan kebenarannya secara ilmiah dan terbuka atas masukan serta saran-saran yang membangun sehubungan dengan pendekatan dan perumusan masalah. Dengan demikian penelitian ini asli baik dari segi subtansi maupun dari segi permasalahan.

\section{F. Kerangka Teori dan Konsep \\ 1. Kerangka Teori}

Kerangka teori merupakan landasan dari teori atau dukungan teori dalam membangun atau memperkuat kebenaran dari permasalahan yang dianalisis. Kerangka teori dimaksud adalah kerangka pemikiran atau butir-butir pendapat, teori, tesis, sebagai pegangan baik disetujui atau tidak disetujui. ${ }^{13}$

Teori berguna untuk menerangkan atau menjelaskan mengapa gejala spesifik atau proses tertentu terjadi dan satu teori harus diuji dengan menghadapkannya pada faktafakta yang dapat menunjukkan

${ }^{13}$ M. Solly Lubis, Filsafat IImu dan Penelitian, Mandar Maju, Bandung, 2004, hlm. 80. ketidakbenarannya. Menurut Soerjono Soekanto, bahwa "kontinuitas perkembangan ilmu hukum, selain bergantung pada metodologi, aktivitas penelitian dan imajinasi sosial sangat ditentukan oleh teori. ${ }^{14}$

Snelbecker mendefenisikan teori sebagai perangkat proposisi yang terintegrasi secara sintaksis (yaitu yang mengikuti aturan tertentu yang dapat dihubungkan secara logis satu dengan lainnya dengan tata dasar yang dapat diamati) dan berfungsi sebagai wahana untuk meramalkan dan menjelaskan fenomena yang diamati. ${ }^{15}$

Fungsi teori dalam penelitian ini adalah untuk memberikan arahan atau petunjuk dan meramalkan serta menjelaskan gejala yang diamati, dan dikarenakan penelitian ini merupakan penelitian yuridis normatif, maka kerangka teori diarahkan secara khas ilmu hukum. Maksudnya penelitian ini berusaha untuk memahami mengenai penyelesaian tindak pidana penipuan seleksi penerimaan Calon Pegawai Negeri Sipil (CPNS)..

Teori hukum yang digunakan sebagai pisau analisis ${ }^{16}$ dalam penelitian ini adalah:

a. Teori penegakan hukum.

UUD 1945 menegaskan bahwa negara Indonesia berdasarkan atas hukum (Rechtstaat) tidak berdasar atas kekuasaan belaka (Machstaat). Ini berarti bahwa negara Republik Indonesia adalah negara hukum yang demokratis berdasarkan pancasila dan UUD

14 Soerjono Soekanto, Pengantar Penelitian Hukum, UI Press, Jakarta, 2006, hIm. 6.

${ }^{15}$ Snelbecker dalam Lexy J Moleong, Metodologi Penelitian Kualitatif, Remaja Rosdakarya, Bandung, 2003, hlm. 34-35.

${ }^{16}$ Teori sebagai pisau analisis yaitu teori yang digunakan untuk dijadikan panduan dalam melakukan analisis, dengan memberikan penilaian (preskripsi) terhadap temuan fakta atau peristiwa hukum yang ada sudah sesuai dengan teori atau tidak. Selain itu, teori ini juga bisa digunakan untuk menjelaskan fakta dan peristiwa hukum yang terjadi, lihat Mukti Fajar ND dan Yulianto, Dualisme Penelitian Hukum: Normatif dan Empiris, Pustaka Pelajar, Yogyakarta, 2010, hlm. 150. 
Media Komunikasi dan Informasi Hukum dan Masyarakat

1945, menjunjung tinggi hak asasi manusia dan menjamin semua warga negara bersamaan kedudukannnya dalam hukum dan pemerintahan serta wajib menjunjung hukum dan pemerintahan itu dengan tidak ada kecualinya.

$$
\text { Penjelasan UUD } 1945 \text { itu }
$$

menerangkan bahawa pemerintahan berdasar atas sistem konstitusional (hukum dasar) tidak absolutisme (kekuasaan yang terbatas), karena kekuasaan eksekutif dan administrasi harus berdasarkan atas sistem konstitusional tidak bersifat absolut. Artinya dministrasi dalam menjalankan tugasnya dibatasi oleh perundang-undangan. ${ }^{17}$

Terdapat tujuh poin ketentuan pokok sistem pemerintahan negara yang tertera dalam UUD 1945 diantaranya adalah :

1) Indonesia adalah negara yang berdasarkan atas hukum (rechtstaat)

2) Sistem konstitusional

3) Kekuasaan negara tertinggi ditangan Majelis Permusyawaratan Rakyat (MPR)

4) Presiden ialah penyelenggara negara yang tertinggi di bawah Majelis Permusyawaratan Rakyat (MPR)

5) Presiden tidak bertanggungjawab terhadap Dewan Perwakilan Rakyat (DPR)

6) Menteri Negara ialah pembantu presiden dan Menteri Negara tidak bertanggungjawab kepada Dewan Perwakilan Rakyat (DPR)

7) Kekuasaan Kepala Negara tidak terbatas. $^{18}$

Berbicara mengenai negara hukum tentunya harus mengetahui perihal sifat dan ciri-ciri negara hukum, melalui UUD 1945 telah diketahui landasan konstitusional dari negara hukum Indonesia. Namun dalam hal sifat dan ciri-ciri dari negara hukum ini kiranya perlu disimak hasil simposium yang diselenggarakan oleh Universitas Indonesia tahun 1966 di Jakarta. Dalam simposium itu diputuskan

17 C.S.T Kansil, Hukum Tata Negara Rapublik Indonesia, Rineka Cipta, Jakarta, 2000, hlm. 90

18 UUD 1945 Hasil Amandemen dan Proses Amandemen UUD 1945 secara lengkap (pertama 2009keempat 2002), Sinar Grafika, Jakarta, 2002, hlm. 67-69 sebagai berikut; " Sifat negara hukum itu ialah di mana alat perlengkapannya hanya dapat bertindak menurut dan terkait kepada aturanaturan yang telah ditentukan lebih dahulu oleh alat-alat perlengkapan yang dikuasakan untuk membuat aturan itu atau singkatnya disebut prinsip "rule of law". ${ }^{19}$

Menurut Ismail Suny dalam CST Kansil mengatakan bahwa negara hukum Indonesia menganut unsur-unsur sebagai berikut :

1) Menjunjung tinggi hukum

2) Adanya pembagian kekuasaan

3) Adanya perlindungan terhadap hak-hak asasi manusia serta remedi-remedi prosedural untuk mempertahankannya

4) Dimungkinkan adanya peradilan administrasi. ${ }^{20}$

Bagir Manan menyebutkan bahwa menurutnya ciri-ciri negara hukum (rechtstaat) adalah :

1) Pemerintahan berdasarkan peraturan perundang-undangan/ legalitas

2) Adanya perlindungan terhadap hak-hak asasi manusia (HAM)

3) Adanya pemisahan dan pembagian kekuasaan negara, menjamin perlindungan HAM

4) Adanya Peradilan Administrasi ${ }^{21}$

UUD 1945 sebagai hukum dasar tertulis hanya mengatur dasar-dasar kehidupan bernegara dalam garis besarnya saja sementara dalam aplikasi dan penjabarannya sangat tergantung dalam politik hukum, produk perundang-undangan serta pelaksanaan hukum atau law enforcement.

Kinerja reformasi hukum sesuai ketetapan MPR No.IV/MPR/2000 serta UU

19 Bambang Waluyo, Implementasi Kekuasaan Kehakiman RI, Sinar Grafika, Jakarta, 2001, hlm. 2

${ }^{20}$ C.S.T Kansil, Op.Cit, hlm. 91.

21 Bagir Manan, Pertumbuhan dan Perkembangan Konstitusi Suatu Negara, Mandar Maju, Bandung, 2005, hlm. 24 
Media Komunikasi dan Informasi Hukum dan Masyarakat

No.25 Tahun 2000 tentang Program

Pembangunan Nasional (Propenas) memiliki agenda diantaranya :

1) Reformasi dibidang peraturan perundangundangan (legislation reform)

2) Reformasi Peradilan (judicial reform)

3) Reformasi aparatur penegak hukum (enforcement apparatur reform)

4) Penyelesaian kasus-kasus pelanggaran HAM dan KKN (urgent 7 strategic enforcement action)

5) Menumbuhkan budaya taat hukum (legal culture reform)

Hukum harus ditegakkan karena hukum mempunyai tujuan untuk mengatur masyarakat agar teratur, damai dan adil dengan mengadakan keseimbangan antara kepentingan yang dilindungi sehingga tiap-tiap anggota masyarakat memperoleh sebanyak mungkin apa yng menjadi haknya. Penegakan hukum merupakan suatu proses untuk mewujudkan keinginan-keinginan dalam hukum agar menjadi kewajiban dan ditaati oleh masyarakat. ${ }^{22}$

Arti penegakan hukum secara konseptual terletak pada kegiatan menyerasikan hubungan nilai-nilai yang dijabarkan di dalam kaedah-kaedah yang mantap dan mengejawantah serta sikap tindak sebagai rangkaian penjabaran nilai akhir dan untuk menciptakan, memelihara dan mempertahankan pergaulan hidup ${ }^{23}$. Penegakan hukum tidak bisa terlepas dari hak asasi manusia, namun dengan adanya alat-alat paksa khusus (bijzonder dwangmiddelen) yang dimaksud alat paksa disini bukan merupakan

22 lbid, hlm. 55

23 Soerjono Soekanto, Faktor-Faktor Yang Mempengaruhi Penegakan Hukum, Raja Grafindo Persada, Jakarta, 2004, hlm. 5 pemaksaan fisik melainkan alat pemaksa yang sah diatur oleh ketentuan perundangundangan seperti penangkapan, penahanan dan penyitaan. ${ }^{24}$

Penegakan hukum menurut Satjipto Raharjo dan Liliana Tedjosaputro, adalah suatu proses untuk mewujudkan keinginan-keinginan hukum menjadi kenyataan. Keinginankeinginan hukum disini adalah pikiran-pikiran badan pembuat undang-undang yang dirumuskan dalam peraturan perundangundangan hukum itu, dan ini akan turut menentukan bagaimana penegakan hukum itu dijalankan. ${ }^{25}$

Satjipto dan Liliana mengemukakan, bahwa penegakan hukum dapat bersifat preventif, represif dan kuratif serta dapat juga ditetapkan pada bidang hukum pidana, perdata dan administrasi. Penegakan hukum preventif adalah usaha pencegahan kejahatan, upaya untuk menjaga agar orang atau masyarakat tidak melakukan kejahatan. Penegakan hukum represif adalah segala tindakan yang dilakukan aparatur penegak hukum sesudah terjadi kejahatan. Sedangkan penegakan hukum kuratif adalah penegakan hukum preventif dalam arti seluas-luasnya dalam usaha penanggulangan kejahatan yang lebih menitikberatkan pada tindakan terhadap orang yang melakukan kejahatan. Kesemua sistem penegakan hukum tersebut masing-masing didukung dan dilaksanakan oleh alat perlengkapan negara atau aparatur penegak hukum yang mempunyai aturannya masingmasing. ${ }^{26}$

${ }^{24}$ Ibid, hal. 7

25 Liliana Tedjosaputro, Etika Profesi Notaris Dalam Penegakan Hukum Pidana, Bigraf Publishing, Yogyakarta, 2005, hlm. 55

${ }_{26} \mathrm{lbid}, \mathrm{hlm} .77$ 
Media Komunikasi dan Informasi Hukum dan Masyarakat

Mochtar Kusumaatmaja menyatakan bahwa hukum tanpa kekuasaan adalah anganangan, sedangkan kekuasaan tanpa hukum adalah kelaliman. Sehingga untuk tegaknya hukum perlu kekuasaan yang mendukungnya, juga sebaliknya kekuasaan harus dibatasi kewenangannya oleh aturan-aturan hukum. ${ }^{27}$

Masalah pokok dari penegakan hukum sebenarnya terletak pada faktor-faktor yang mempengaruhinya, dimana kelima faktor tersebut saling berkaitan. Oleh karenanya merupakan esensi dari penegakan hukum, serta merupakan tolok ukur dari efektivitasnya penegakan hukum, yaitu :

1) Faktor hukumnya sendiri, yang dalam hal ini undang-undang beserta peraturan pelaksanaannya

2) Faktor penegak hukum, yaitu pihak-pihak yang menerapkan hukum

3) Faktor sarana atau fasilitas yang mendukung penegakan hukum

4) Faktor masyarakat, yakni masyarakat di mana hukum itu diterapkan

5) Faktor kebudayaan, yakni hasil cipta, rasa dan karsa dari manusia dalam kehidupannya. ${ }^{28}$

Pelaksanaan hukum dapat berlangsung secara normal dan damai tetapi dapat juga karena pelanggaran hukum. Dalam hal ini hukum yang dilanggar itu harus ditegakkan, melalui penegakan hukum inilah hukum menjadi kenyataan. Dalam penegakan hukum ada tiga unsur yang harus selalu diperhatikan, yaitu kepastian hukum, kemanfaatan dan keadilan. Supremasi hukum harus dilaksanakan sesuai dengan ungkapan "fiat justicia et pereat mundus" ( meskipun langit runtuh hukum harus ditegakkan). ${ }^{29}$

Hukum menetapkan apa yang harus dilakukan dan apa yang boleh dilakukan serta

\footnotetext{
${ }^{27}$ Mochtar Kusumaatmaja, Konsep Hukum Dalam Pembangunan, Alumni, Bandung, 2002, hlm. 5

${ }^{28}$ Soerjono Soekanto, Op. Cit, hlm. 3

${ }^{29}$ Sudikno dan Pitlo, Bab-Bab Tentang Penemuan Hukum, Citra Aditya Bakti, Bandung, 2003, hlm. 1
}

apa yang tidak boleh dilakukan (dilarang). Sasaran hukum yang hendak dituju bukan saja orang yang nyata-nyata berbuat melawan hukum, melainkan juga perbuatan hukum yang mungkin akan terjadi, dan kepada alat perlengkapan negara untuk bertindak menurut hukum. Sistem bekerjanya hukum yang demikian itu merupakan salah satu bentuk penegakan hukum.

b. Sistem Peradilan Pidana.

Istilah sistem peradilan pidana (criminal justice system) menunjukan mekanisme kerja dalam penanggulangan kejahatan yang menggunakan dasar pendekatan sistem. Pendekatan sistem adalah pendekatan yang menggunakan segenap unsur yang terlbat di dalamnya sebagai suatu kesatuan dan saling berhubungan (interelasi) dan saling mempengaruhi satu sama lain. Melalui pendekatan ini kepolisian, kejaksaan, pengadilan dan lembaga pemasyarakatan merupakan unsur penting dan berkaitan satu sama lain. ${ }^{30}$

Sistem peradilan pidana sebagai suatu sistem pada dasarnya merupakan suatu open system. Open system merupakan suatu sistem yang di dalam gerakan mencapai tujuan baik tujuan jangka pendek (resosialisasi), jangka menegah (pencegahan kejahatan) maupun jangka panjang (kesejahteraan sosial) sangat dipengaruhi oleh lingkungan masyarakat dan bidang-bidang kehidupan manusia, maka sistem peradlian pidana dalam geraknya akan selalu mengalami interface (interaksi, interkoneksi, interdependensi) dengan lingkungannya dalam peringkatperingkat, masyarakat, ekonomi, politik,

30 Mardjono Reksodiputro, Sistem Peradilan Pidana Indonesia (Melihat Kepada Kejahatan Dan Penegakan Hukum Dalam Batas-Batas Toleransi), Fakultas Hukum Unversitas Indonesia, 2003, hlm. 1 
Media Komunikasi dan Informasi Hukum dan Masyarakat

pendidikan dan teknologi, serta subsistemsubsistem dari sistem peradilan pidana itu sendiri (subsystem of criminal justice system) ${ }^{31}$

Komponen sistem peradilan pidana yang lazim diakui, baik dalam pengetahuan mengenai kebijakan kriminal (criminal policy) maupun dalam praktik penegakan hukum, terdiri atas unsur kepolisian, kejaksaan, pengadilan, dan lembaga pemasyarakatan. ${ }^{32}$

a. Kepolisian

Kepolisian sebagai salah satu komponen sistem peradilan pidana merupakan lembaga yang secara langsung berhadapan dengan tindak pidana yang terjadi dalam masyarakat. Undang-Undang Nomor 2 Tahun 2002 tentang Kepolisian Negara Republik Indonesia memberikan definisi kepolisian sebagai hal-ihwal yang berkaitan dengan fungsi dan lembaga polisis sesuai dengan peraturan perundang-undangan.

Fungsi kepolisian berdasarkan Pasal 2 Undang-Undang Nomor 2 Tahun 2002 tentang Kepolisian Negara Republik Indonesia adalah salah satu fungsi pemerintahan negara di bidang pemeliharaan keamanan dan ketertiban masyarakat, penegakan huku, perlindungan, pengayoman, dan pelayanan kepada masyarakat."

Kepolisian merupakan subsistem dalam sistem peradilan pidana yang cukup menentukan keberhasilan dan kerja keseluruhan sistem dalam memberikan pelayanan kepada masyarakat. $\mathrm{Hal}$ ini dikarenakan kepolisian merupakan subsistem yang secara langsung berhubungan dengan pelaku tindak pidana dan masyarakat,

31 Romli Atmasasmita, Sistem Peradilan Pidana(Criminal Justice System) Perspektif Eksistensialisme Dan Abolisionalisme, Bina Cipta, Jakarta, 2006, hlm. 15.

32 Ibid, hlm. 24 sehingga tugas dan tanggung jawab kepolisian dapan dikatakan lebih besar daripada subsistem lainnya.

b. Kejaksaan

Kejaksaan dalam sistem peradilan pidana bekerja setelah ada pelimpahan perkara dari kepolisian. Kejaksaan merupakan lembaga pemerintahan dibidang penuntutan serta tugas lain yang ditetapkan berdasarkan undang-undang. Pasal 13 KUHAP disebutkan bahwa jaksa merupakan penuntut umum yang diberi wewenang oleh undang-undang untuk melakukan penuntutan dan pelaksanaan putusan hakim.

c. Pengadilan

Pengadilan merupakan tempat berlangsungnya proses peradilan, sedangkan kewenangan mengadakan pengadilan itu sendiri berada ditangan lembaga kehakiman. Hal ini tercantum dalam Undang-Undang Nomor 48 Tahun 2009 Tentang Kekuasaan Kehakiman. Tugas pengadilan adalah menerima, memeriksa, mengadili dan menyelesaikan perkara yang diajukan kepadanya. Tugas ini meliputi pengadilan negeri, pengadilan tinggi, dan mahkamah agung. Selain itu pengadilan berkewajiban pula untuk mewujudkan membantu pencari keadilan serta berkewajiban untuk mewujudkan suatu peradilan yang sederhana, cepat, dan biaya ringan sesuai dengan asas peradilan yang ditetapkan oleh KUHAP.

d. Lembaga Pemasyarakatan

Lembaga pemasyarakatan merupakan lembaga terakhir yang berperan dalam proses peradilan pidana. Sebagai tahapan akhir dari proses peradilan pidana lembaga pemasyarakatan mengemban harapan dan tujuan dari sistem peradilan pidana yang diantaranya berusaha agar pelaku tindak 
Media Komunikasi dan Informasi Hukum dan Masyarakat

pidana tidak lagi mengulangi tindak pidana yang pernah dilakukannya.

e. Advokat

Advokat adalah orang yang berprofesi memberi jasa hukum, baik didalam maupun diluar pengadilan yang memenuhi persyaratan berdasarkan ketentuan undang-undang. Jasa hukum adalah jasa yang diberikan advokat berupa memberikan konsultasi hukum, bantuan hukum, menjalankan kuasa, mewakili, mendampingi, membela dan melakukan landasan hukum lain untuk kepentingan hukum klien. Diundangkannya Undang-Undang Nomor 18 Tahun 2003 Tentang Advokat, maka advokat juga menjadi bagian (subsistem) dari sistem peradilan pidana, hal ini ditegaskna dalam Pasal 5 ayat (1) undang-undang tersebut yang menyebutkan bahwa advokat berstatus sebagai penegak hukum, bebas dan mandiri yang dijamin oleh hukum dan peraturan perundang-undangan.

\section{Landasan Konsep.}

Konsepsi adalah bagian terpenting dari teori, peranan konsepsi dalam penelitian ini untuk menggabungkan teori dengan observasi, antara abstrak dan kenyataan. Menurut Burhan Ashshofa, suatu konsep merupakan abstraksi mengenai suatu fenomena yang dirumuskan atas dasar generalisasi dari jumlah karakteristik kejadian, keadaan, kelompok, atau individu tertentu. ${ }^{33}$ Oleh karena itu dalam penelitian ini menggunakan konsep-konsep sebagai berikut :

a. Penindakan adalah adalah proses, cara, perbuatan menindak ${ }^{34}$ yaitu tindakan yang dilakukan bagi anggota polisi yang melewati kewenangannya.

33 Burhan Ashshofa, Metodologi Penelitian Hukum, Rineka Cipta, Jakarta, 2006, hlm. 19.

${ }^{34}$ WJS. Poerwadarminta, Kamus Umum Bahasa Indonesia, Balai Pustaka, Jakarta, 2008, hlm. 1277. b. Propam (Profesi dan Pengamanan) adalah unsur pelaksana staf khusus Polda yang berada di bawah Kapolda. Bidang Propam (BidPropam) bertugas membina dan menyelenggarakan fungsi pertanggung jawaban profesi, pengamanan internal, penegakan disiplin dan ketertiban di lingkungan Polda, termasuk pelayanan pengaduan masyarakat Tentang adanya penyimpangan tindakan anggota Polri atau PNS termasuk pemberian rehabilitasi sesuai ketentuan yang berlaku

c. Polisi Lalu Lintas adalah unsur pelaksana yang bertugas menyelenggarakan tugas kepolisian mencakup penjagaan, pengaturan, pengawalan dan patroli, pendidikan masyarakat dan rekayasa lalu lintas, registrasi dan identifikasi pengemudi atau kendaraan bermotor, penyidikan kecelakaan lalu lintas dan penegakan hukum dalam bidang lalu lintas, guna memelihara keamanan, ketertiban dan kelancaran lalu lintas.

d. Melampaui kewenangannya dalam menjalankan tugas adalah melanggar aturan tertulis yang menjadi dasar kewenangannya, memiliki maksud yang menyimpang walaupun perbuatan sudah sesuai dengan peraturan serta berpotensi merugikan negara.

\section{G. Metode Penelitian}

Metode penelitian adalah upaya untuk menemukan, mengembangkan dan menguji kebenaran suatu pengetahuan dimana usaha tersebut dilakukan dengan menggunakan metode ilmiah. ${ }^{45}$ Metode penelitian berisikan uraian tentang metode atau cara yang peneliti

${ }^{45}$ Sutrisno Hadi, Metodologi Riset, Andi Offset, Yogyakarta, 2009, hlm. 3 
Media Komunikasi dan Informasi Hukum dan Masyarakat

gunakan untuk memperoleh data atau informasi. ${ }^{46}$ Metode penelitian ini berfungsi sebagai pedoman dan landasan tata cara dalam melakukan oprasional penelitian untuk menulis suatu karya ilmiah yang peneliti lakukan.

Penelitian hukum pada dasarnya dibagi dalam 2 (dua) jenis yaitu penelitian normatif dan penelitian empiris. Penelitian normatif merupakan penelitian dengan menggunakan data sekunder sehingga disebut pula penelitian kepustakaan, sedangkan yang dimaksud dengan penelitian empiris adalah penelitian secara langsung di masyarakat ada yang melalui questioner (daftar pertanyaan) ataupun wawancara langsung. ${ }^{35}$

\section{Jenis Penelitian}

Penelitian ini bersifat deskriptif analisis yaitu penelitian yang menggambarkan, menelaah, menjelaskan serta menganalisa peraturan perundang-undangan yang berkaitan pada tujuan penelitian ini. Tujuan dalam penelitian deskriptif adalah untuk menggambarkan secara tepat sifat-sifat individu, keadaan, gejala atau kelompok tertentu, atau untuk menentukan frekuensi atau penyebaran suatu gejala atau frekuensi adanya hubungan tertentu antara gejala dan gejala lain dalam masyarakat. ${ }^{36}$ Maksud utama analisis terhadap bahan hukum adalah mengetahui makna yang dikandung oleh istilah-istilah yang digunakan dalam aturan undang-undang secara konsepsional,

\footnotetext{
${ }^{46}$ Zainuddin Ali, Metode Penelitian Hukum, Sinar Grafika, Jakarta, 2009, hlm. 105

35 Soerjono Soekanto dan Sri Mamudji, Penelitian Hukum Normatif, Rajawali Pers, Jakarta, 2015, hlm. 1.

36 Kontjaraningrat, Metode-Metode Penelitian Masyarakat, Gramedia, Jakarta, 2007, hlm. 42.
}

sekaligus mengetahui penerapannya dalam praktik dan putusan-putusan hukum. ${ }^{37}$

Ditinjau dari sudut metode yang dipakai maka penelitian ini dapat digolongkan dalam jenis penelitian hukum sosiologis (empiris), yaitu sebagai usaha melihat pengaruh berlakunya hukum positif terhadap kehidupan masyarakat, karena dalam penelitian ini penulis langsung melakukan penelitian pada lokasi atau tempat yang diteliti guna memberikan gambaran secara lengkap dan jelas tentang permasalahan yang sedang diteliti. Selain itu dalam penelitian hukum sosiologis melihat korelasi antara hukum dengan masyarakat, sehingga mampu mengungkap efektifitas berlakunya hukum dalam masyarakat.

Menurut Soerjono Soekanto dan Sri Manudji bahwa penelitian hukum sosiologis (empiris) mencakup, penelitian terhadap identifikasi hukum (tidak tertulis) dan penelitian terhadap efektifitas hukum. ${ }^{38}$ Penelitian hukum sosiologis atau empiris hendak mengadakan pengukuran terhadap peraturan perundangundangan tertentu mengenai efektivitasnya, maka definis-definisi operasionil dapat diambil dari peraturan perundang-undangan tersebut.

\section{Sifat Penelitian}

Sifat penelitian ini adalah deskriptif analitis yang memberikan argumentasiargumentasi terhadap hasil penelitian yang telah dilakukan, memberikan perspektif (penilaian) mengenai benar atau salah atau apa yang seharusnya dan semestinya atau bagaimana menurut hukum yang berlaku

\footnotetext{
37 Johnny Ibrahim, Teori dan Metodologi Penelitian Hukum Normatif, Bayumedia Publishing, Malang, 2008, hlm. 310 45
} 
Media Komunikasi dan Informasi Hukum dan Masyarakat

terhadap fakta atau peristiwa-peristiwa kongkrit yang diungkapkan di dalam penelitian. ${ }^{39}$

Penelitan ini berupaya untuk memberikan justifikasi atau penilaian benar atau salah atau bagaimana seharusnya dan semestinya menurut ketentuan hukum yang berlaku terhadap peristiwa kongkrit di lapangan, misal peristiwa kongrit tersebut dapat dideskripsikan dari penerapan sanksi kepada anggota Polri atas pelanggaran kode etik. Sifat penelitian ini selain berupaya mejelaskan hubungan antar variabel di dalam penelitian ini, juga menggambarkan (deskripsi) mengenai fakta-fakta hukum, sekaligus menganalisa dengan argumentasi-argumentasi normatif untuk memberikan justifikasi atau penilaian benar atau salah menurut hukum atau bagaimana seharusnya menurut hukum terhadap fakta atau peristiwa kongkrit tersebut. ${ }^{40}$

\section{Sumber data.}

Sumber data penelitian ini adalah :

a. Data primer.

Sumber data utama, dalam penelitian ini juga digunakan data primer sebagai data pendukung yang diperoleh dari wawancara. Wawancara dilakukan dengan pihak-pihak yang telah ditentukan sebagai informan atau narasumber dikhususkan untuk pemecahan masalah yang masih memerlukan informasi lebih lanjut dalam memastikan validitas data-data sekunder yang telah diperoleh. Dalam wawancara ini akan diperoleh data dari sumber pertama, dalam hal ini adalah Kepala Bidang Propam Polrestabes Medan.

b. Data sekunder
Data sekunder yang dimaksud antara lain meliputi bahan hukum primer, bahan hukum sekunder, dan bahan hukum tertier berupa norma dasar, perundangundangan, hasil penelitian ilmiah, bukubuku, dan lain-lain sebagainya. ${ }^{41}$

Sumber bahan hukum yang digunakan dalam penelitian ini berasal dari data sekunder yang diperoleh melalui :

1) Bahan hukum primer

Bahan hukum primer adalah bahan hukum yang mempunyai kekuatan mengikat sebagai landasan utama yang dipakai dalam rangka penelitian diantaranya adalah Kitab UndangUndang Hukum Pidana, UndangUndang Nomor 2 Tahun 2002 Tentang Kepolisian Negara Republik Indonesia, Peraturan Pemerintah Nomor 1 Tahun 2003 Tentang Pemberhentian Anggota Kepolisian Negara Republik Indonesia, Keputusan Kapolri No. Pol: KEP/01/ VII/2003 Tentang Naskah Kode Etik Profesi Kepolisian Negara Republik Indonesia, Peraturan Kepala Kepolisian Negara Republik Indonesia Nomor 14 Tahun 2011 Tentang Kode Etik Profesi Kepolisian Negara Republik Indonesia.

2) Bahan hukum sekunder, yaitu semua publikasi tentang hukum yang bukan merupakan dokumen-dokumen resmi yang meliputi buku-buku teks, kamus hukum. ${ }^{42}$

3) Bahan hukum tertier, yaitu bahan hukum yang memberikan petunjuk

41 Amiruddin dan Zainal Asikin, Pengantar Metode Penelitian Hukum, Raja Grafindo Persada, Jakarta, 2004, hlm.30

Mahmud, Penelitian Hukum, Edisi Pertama Cetakan keenam, Kencana Prenada Media Group, Jakarta, 2011, hlm. 141. 
Media Komunikasi dan Informasi Hukum dan Masyarakat

atau penjelasan terhadap bahan hukum primer dan sekunder. Penulis menggunakan Kamus Besar Bahasa Indonesia. Penulis dalam hal ini menggunakan sumber data lain, yaitu bahan non hukum, ${ }^{43}$ yaitu bahan yang merupakan bukan berasal dari hukum tetapi dipandang perlu untuk penulisan serta mempunyai kaitan dengan topik penelitian.

\section{Teknik Pengumpulan Data}

a. Wawancara (Interview)

Wawancara atau interview merupakan salah satu metode dalam mengumpulkan data dengan pola khusus yaitu dalam bentuk interaksi dimana pewawancara mengajukan pertanyaan seputar masalah penelitian kepada responden. Dalam melakukan wawancara ini, pewawancara menggunakan metode wawancara terstruktur yang merupakan suatu metode wawancara dimana pewawancara telah menyiapkan terlebih dahulu daftar pertanyaan yang hendak disampaikan kepada responden.

b. Studi Kepustakaan

Mengkaji, menelaah dan menganalisis berbagai literatur yang berhubungan dengan permasalahan yang sedang diteliti.

\section{Alat Pengumpul data}

a. Studi Dokumen memperolah data sekunder perlu dilakukan studi dokumetasi yaitu dengan cara mempelajari peraturanperaturan, teori dan dokumen lain berhubungan dengan penindakan
Propam (Profesi can Pengamanan) terhadap anggota polisi lalu lintas yang melampaui kewenangannya dalam menjalankan tugas.

b. Pedoman Wawancara

Pedoman Wawancara adalah panduan dalam melakukan kegiatan wawancara yang terstrutur dan telah ditetapkan oleh pewawancara dalam mengumpulkan data-data penelitian. Para informan yang dipilih untuk mendukung penelitian ini yaitu :

1) Kepala Bidang Propam

2) Anggota Kepolisian Resort Kota Besar Kota Medan.

\section{Analisa Data}

Data penelitian dianalisis secara kualitatif artinya data yang berdasarkan uraian kalimat atau data tidak dianalisis dengan menggunakan statistik atau matematika ataupun sejenisnya, yaitu apa yang dinyatakan responden secara tertulis ataupun lisan dan perilaku nyata yang diteliti dan dipelajari sebagai sesuatu yang utuh. $^{44}$ Sedangkan metode berpikir yang digunakan penulis yaitu deduktif, yakni pengerucutan dari bagian umum yang merupakan permasalahan umum kepada permasalahan yang lebih khusus. ${ }^{45}$

\section{PEMBAHASAN}

\section{A. Faktor Penyebab Penyalahgunaan} Wewenang Yang Dilakukan Oleh Polisi Lalu Lintas Di Polrestabes Medan

1. Polisi Republik Indonesia (Polri).

a. Pengertian Polisi Republik Indonesia.

Menurut Pudi Rahardi bahwa polisi dan kepolisian memiliki arti yang berbeda

\footnotetext{
${ }^{44}$ Soerjono Soekanto, Op.Cit, hlm. 32

${ }^{45}$ Ibid., hlm. 11
} 
Media Komunikasi dan Informasi Hukum dan Masyarakat

dinyatakan bahwa istilah polisi adalah sebagai organ atau lembaga pemerintahan yang ada dalam negara, Sedangkan istilah kepolisian adalah sebagai organ dan sebagi fungsi. Sebagi organ yaitu suatu lembaga pemerintahan yang terorganisasi dan terstruktur dalam organisasi negara. Sedangkan sebagai fungsi, yakni tugas dan wewenang serta tanggung jawab lembaga atas kuasa Undang-undang untuk menyelenggarakan fungsinya, antara lain pemeliharaan keamanan, ketertiban masyarakat, penegak hukum pelindung, pengayom, pelayananan masyarakat. ${ }^{46}$

Menurut Pasal 1 butir 1 UndangUndang Nomor 2 Tahun 2002 tentang kepolisian, "Kepolisian adalah segala hal-ihwal yang berkaitan dengan fungsi dan lembaga polisi sesuai dengan peraturan perundangundangan".

Cendekiawan di bidang Kepolisian menyatakan bahwa dalam kata Polisi terdapat 3 pengertian, yaitu:

a. Polisi sebagai fungsi.

b. Polisi sebagai organ kenegaraan.

c. Polisi sebagai pejabat/tugas. ${ }^{47}$

Menurut Pasal 2 Undang-Undang Nomor 2 Tahun 2002 tentang Kepolisian Negara Republik Indonesia, fungsi Polri adalah: "Fungsi kepolisian adalah salah satu fungsi pemerintahan negara di bidang pemeliharaan keamanan dan ketertiban masyarakat,penegakan hukum, perlindungan, pengayoman, dan pelayanankepada masyarakat".

Polri dalam menjalankan fungsi sebagai aparat penegakan hukum, polisi wajib memahami asas-asas hukum yang digunakan sebagai bahan pertimbangan dalam pelaksanaan tugas, yaitu sebagai berikut:

a. Asas legalitas, dalam melaksanakan tugasnya sebagai penegak hukum wajib tunduk pada hukum.

b. Asas kewajiban, merupakan kewajiban polisi dalam menangani permasalahan masyarakat yang bersifat diskresi, karena belum diatur dalam hukum.

c. Asas partisipasi, dalam rangka mengamankan lingkungan masyarakat polisi mengkoordinasikan pengamanan Swakarsa untuk mewujudkan ketaatan hukum di kalangan masyarakat.

d. Asas preventif, selalu mengedepankan tindakan pencegahan daripada penindakan (represif) kepada masyarakat.

e. Asas subsidiaritas, melakukan tugas instansi lain agar tidak menimbulkan permasalahan yang lebih besar sebelum ditangani oleh instansi yang membidangi. ${ }^{48}$

Pasal 4 Undang-Undang Nomor 2 Tahun 2002 Tentang Kepolisian Negara Republik Indonesia diatur juga tentang tujuan dari Polri yaitu: "Kepolisian Negara Republik Indonesia bertujuan untuk mewujudkan keamanan dalam negeri yang meliputi terpeliharanya keamanan dan ketertiban masyarakat, tertib dan tegaknya hukum, terselenggaranya perlindungan, pengayoman, dan pelayanan kepada masyarakat, serta terbinanya ketenteraman masyarakat dengan menjunjung tinggi hak asasi manusia".

Kedudukan Polri sekarang berada di bawah Presiden menurut Pasal 8 UndangUndang Nomor 2 Tahun 2002 Tentang Kepolisian Negara Republik Indonesia yang menyatakan:

a. Kepolisian Negara Republik Indonesia berada di bawah Presiden.

b. Kepolisian Negara Republik Indonesia dipimpin oleh Kapolri yang dalam pelaksanaan tugasnya bertanggung jawab

\footnotetext{
46 Pudi Rahardi, Profesionalisme dan Reformasi Polri, Laskbang Mediatama, Surabaya, 2007, hlm. 5

47 lbid., hlm. 6
}

48 lbid., hlm.7. 
Media Komunikasi dan Informasi Hukum dan Masyarakat

kepada Presiden sesuai dengan peraturan perundang-undangan.

\section{Tugas dan Wewenang Polisi Republik Indonesia}

Tugas dan wewenang Polri di atur dalam Bab III mulai Pasal 13 sampai 14 Undang-Undang Nomor 2 Tahun 2002 Tentang Kepolisian Negara Republik Indonesia. Tugas, fungsi, dan kewenangan dijalankan atas kewajiban untuk mengadakan pengawasan secara intensif dan bila perlu dengan paksaan yang dilakukan dengan cara melaksanakan kewajiban umum dengan perantara pengadilan, dan memaksa yang diperintah untuk melaksanakan kewajiban umum tanpa perantara pengadilan. ${ }^{49}$

Pasal 13 Undang-Undang Nomor 2 Tahun 2002 Tentang Kepolisian Negara Republik Indonesia menyebutkan bahwa tugas pokok Kepolisian Negara Republik Indonesia adalah:

a. Memelihara keamanan dan ketertiban masyarakat.

b. Menegakkan hukum.

c. Memberikan perlindungan, pengayoman, dan pelayanan kepada masyarakat.

Pasal 14 Undang-Undang Nomor 2 Tahun 2002 Tentang Kepolisian Negara Republik Indonesia menyebutkan bahwa:

a. Dalam melaksanakan tugas pokok sebagaimana dimaksud dalam Pasal 13, Kepolisian Negara Republik Indonesia bertugas.

b. Melaksanakan pengaturan, penjagaan, pengawalan, dan patroli terhadap kegiatan masyarakat dan pemerintah sesuai kebutuhan.

49 Sadjijono, Hukum Kepolisian Perspektif Kedudukan dan Hubungan Dalam Hukum Administrasi, LaskBang PRESSindo, Yogyakarta, 2006, hlm. 14 c. Menyelenggarakan segala kegiatan dalam menjamin keamanan, ketertiban,dan kelancaran lalu lintas di jalan.

d. Membina masyarakat untuk meningkatkan partisipasi masyarakat, kesadaran hukum masyarakat serta ketaatan warga masyarakat terhadap hukum dan peraturan perundang-undangan.

e. Turut serta dalam pembinaan hukum nasional.

f. Memelihara ketertiban dan menjamin keamanan umum.

g. Melakukan koordinasi, pengawasan, dan pembinaan teknis terhadap kepolisian khusus, penyidik pegawai negeri sipil, dan bentuk-bentuk pengamanan swakarsa.

h. Melakukan penyelidikan dan penyidikan terhadap semua tindak pidana sesuai dengan hukum acara pidana dan peraturan perundang-undangan lainnya.

i. Menyelenggarakan identifikasi kepolisian, kedokteran kepolisian, laboratorium forensik dan psikologi kepolisian untuk kepentingan tugas kepolisian.

j. Melindungi keselamatan jiwa raga, harta benda, masyarakat, dan lingkungan hidup dari gangguan ketertiban dan/atau bencana termasuk memberikan bantuan dan pertolongan dengan menjunjung tinggi hak asasi manusia.

k. Melayani kepentingan warga masyarakat untuk sementara sebelumditangani oleh instansi dan/atau pihak yang berwenang.

I. Memberikan pelayanan kepada masyarakat sesuai dengan kepentingannyadalam lingkup tugas kepolisian.

m. Melaksanakan tugas lain sesuai dengan peraturan perundang-undangan. 
Media Komunikasi dan Informasi Hukum dan Masyarakat

n. Tata cara pelaksanaan ketentuan sebagaimana dimaksud dalam ayat (1) huruf $f$ diatur lebih lanjut dengan Peraturan Pemerintah. Menurut semboyan Tribrata, tugas dan wewenang Polri adalah: Kami Polisi Indonesia:

1) Berbhakti kepada Nusa dan Bangsa dengan penuh Ketaqwaan TerhadapTuhan Yang Maha Esa.

2) Menjunjung tinggi kebenaran, keadilan dan kemanusiaan dalam menegakkan hukum Negara Kesatuan Republik Indonesia yang Berdasarkan Pancasila dan UUD 1945.

3) Senantiasa Melindungi, mengayomi dan Melayani masyarakat dengan Keikhlasan utuk mewujudkan keamanan dan ketertiban.

\section{Tugas dan Wewenang Polri dalam Bidang Lalu Lintas}

Polisi lalu lintas adalah bagian dari kepolisian yang diberi tangan khusus di bidang lalu lintas dan karenanya merupakan pengkhususan (spesifikasi) dari tangan polisi pada umumnya. ${ }^{50}$ Polisi lalu lintas yang diberikan tugas yang khusus ini, maka diperlukan kecakapan teknis yang khusus pula.

Akan tetapi, walaupun demikian hal ini tidaklah menghilangkan atau mengurangi tugas Memelihara keamanan dan ketertiban masyarakat pokok yang dibebankan kepada setiap anggota POLRI, karena itu berhadapan dengan keadaan yang dapat mengganggu keamanan dan ketertiban pada umumnyapolisi lalu lintas pun harus bertindak.

Polisi Lalu Lintas adalah bagian dari polisi kota dan mewujudkan susunan pegawai-

50 Adrianus Meliala, Problema Reformasi Polri, Trio Repro, Jakarta, 2012, hlm. 16. pegawai lalu lintas di jalan-jalan. Tugas polisi lalu lintas dapat dibagi dalam dua golongan besar, yaitu:

a. Operatif:

1) Memeriksa kecelakaan lalu lintas.

2) Mengatur lalu lintas.

3) Menegakkan Hukum lalu lintas.

b. Administratif:

1) Mengeluarkan Surat Izin Mengemudi.

2) Mengeluarkan Surat Tanda Kendaraan Bermotor.

3) Membuat statistik/grafik dan pengumpulan semua data yang berhubungan dengan lalu lintas. ${ }^{51}$

Fungsi Kepolisian Bidang Lalu Lintas

(fungsi Lantaspol) dilaksanakan dengan melakukan kegiatan-kegiatan yang meliputi:

a. Penegakan hukum lalu lintas (Police Traffic Law Enforcement),yang dapat bersifat preventif yaitu pengaturan, penjagaan, dan patroli lalu lintas dan represif yaitu penindakan hukum terhadap para pelanggar lalu lintas dan penyidikan kecelakaan lalu lintas.

b. Pendidikan masyarakat tentang lalu lintas (Police Traffic Education).

c. Enjinering lalu lintas (Police Traffic Enginering).

d. Registrasi dan identifikasi pengemudi serta kendaraan bermotor. ${ }^{52}$

Polisi lalu lintas dalam

penyelenggaraan fungsi Lantaspol berperan:

a. Aparat penegak hukum perundangundangan lalu lintas dan peraturan pelaksananya.

b. Aparat yang mempunyai wewenang Kepolisisan Umum.

c. Aparat penyidik kecelakaan lalu lintas.

d. Aparat pendidikan lalu lintas terhadap masyarakat.

e. Penyelenggaran registrasi dan identifikasi pengemudi dan kendaraan bermotor.

f. Pengumpul dan pengelola data tentang lalu lintas

g. Unsur bantuan pengelola data bantuan teknis melalui unit-unit patroli jalan raya (PJR). ${ }^{53}$

${ }^{51}$ Andi Darmanto, Tugas dan Kewenangan Polri (Satuan Lalulintas), Mizan, Bandung, 2017, hlm. 64

52 lbid., halaman 65

53 Suroso, Tugas dan Wewenang Polisi Lalu Lintas Dalam Praktik Penegakan Hukum Pidana, Ghalia Indonesia, Jakarta, 2015, hlm. 47 
Media Komunikasi dan Informasi Hukum dan Masyarakat

Penegakan hukum lalu lintas merupakan bagian dari fungsi Polisi lalu lintas yang berkewajiban agar Undang-Undang lalu lintas ditaati oleh setiap pemakai jalan. Berdasarkan fungsinya, kegiatan penegakan hukum lalu lintas dapat dikelompokkan ke dalam dua bagian yaitu:

a. Preventif

Meliputi kegiatan-kegiatan pengaturan lalu lintas, penjagaan lalu lintas, pengawalan lalu lintas, patroli lalu lintas dimana dalam pelaksanaannya kegiatan-kegiatan tersebut merupakan suatu sistem keamanan lalu lintas saling terkait dan tidak dapat dipisahkan.

\section{b. Represif}

Meliputi penindakan pelanggaran dan penyidikan lalu lintas, dimana

penindakan lalu lintas meliputi penindakan secara edukatif yaitu melakukan penindakan terhadap pelanggar lalu lintas secara simpatik dengan memberikan teguran atau peringatan terhadap pelanggar lalu lintas. Sementara penindakan secara yuridis dapat diartikan sebagai penindakan pelanggaran lalu lintas secara hukum yang meliputi penindakan dengan menggunakan tilang, serta penindakan terhadap pelaku kecelakaan lalu lintas yang menimbulkan korban jiwa dengan menggunakan ketentuan penyidikan. ${ }^{54}$

\section{B. Faktor Penyebab Penyalahgunaan Wewenang yang Dilakukan Oleh Polisi Lalu Lintas}

Polisi adalah profesi mulia (nobile officum) sebagaimana profesi-profesi terhormat lainnya yang memberikan perlindungan dan pengayoman kepada masyarakat. ${ }^{55}$ Prakteknya polisi dalam menjalankan tugasnya dapat juga melakukan penyalahgunaan wewenang.

Beberapa faktor yang mempengaruhi terjadinya penyalahgunaan wewenang, misalnya oleh faktor ekonomi. Dalam hal ini, terkait dengan kurangnya penghasilan yang diperoleh seorang aparat kepolisian yang tidak

\footnotetext{
54 Ibid., hlm. 50

${ }^{55}$ Anton Tabah, Op. Cit, hlm 359
}

sebanding dengan tingginya kebutuhan biaya hidup sehingga berpengaruh pada perilaku untuk mencari penghasilan lebih. Keadaan ini juga semakin di dukung oleh banyaknya anakanak yang mengendarai kendaraan bermotor khususnya roda dua yang belum memiliki surat izin mengemudi, tentunya peluang ini membuat para pelanggar tersebut harus berurusan dengan aparat penegak hukum dalam hal ini polisi lalu lintas. Kesempatan seperti ini dimanfaatkan untuk mendapatkan penghasilan tambahan. ${ }^{56}$

Selain faktor ekonomi, kedekatan emosional dengan aparat kepolisian juga mempengaruhi terjadinya pelanggaran dalam penaggulangan lalu lintas. Kedekatan emosional dalam hal ini meliputi persamaan asal daerah, adanya hubungan keluarga, kesamaan profesi, serta hal-hal lainnya yang menjadikan mereka memiliki latar belakang yang sama dalam suatu hal tertentu. ${ }^{57}$

Kenyataannya selain faktor ekonomi yang dialami oleh aparat kepolisan serta faktor kedekatan emosional aparat kepolisian dengan masyarakat tertentu ada juga hal-hal lain yang mempengaruhi aparat kepolisian dalam menjalankan tugasnya menimbulkan reaksi dari berbagai masyarakat. hal-hal yang perlu di benahi terkait perilaku aparat kepolisian adalah:

1. Masih ada pelanggaran yang dilakukan oleh polisi dalam menyelesaikan pelanggran lalu lintas.

2. Polisi bersikap arogan terhadap masyarakat.

3. Terkadang polisi tidak mematuhi prosedur dalam menjalankan tugas.

4. Masih banyak aparat kepolisian yang menerima uang sogokan dari para pelanggar.

56 Hariandja, Disiplin Berlalu Lintas di Jalan Raya, Airlangga, Jakarta, 2012, hlm. 56.

57 lbid., hlm. 58 
Media Komunikasi dan Informasi Hukum dan Masyarakat

5. Polisi bersikap kasar terhadap masyarakat dan terkesan mencari-cari kesalahan.

6. Terdapat aparat kepolisian yang tidak memenuhi kelengkapan kendaraannya sendiri.

7. Masih banyaknya terjadi pelanggaran lalu lintas. ${ }^{58}$

Berdasarkan hal tersebut, maka polisi dalam melaksanakan tugasnya tidak sesuai dengan peraturan perundang-undangan yang berlaku seperti dalam Pasal 30 Peraturan Pemerintah Republik Indonesia No. 80 tahun 2012 Tentang Tata Cara Pemeriksaan Kendaraan Bermotor Di Jalan Dan Penindakan Pelanggaran Lalu Lintas Dan Angkutan Jalan yang mengemukakan bahwa pembayaran uang denda tilang pelanggaran Lalu Lintas dan Angkutan Jalan dilakukan setelah adanya putusan pengadilan atau dapat dilakukan pada saat pemberian surat tilang dengan cara penitipan kepada bank yang ditunjuk oleh pemerintah. Ketentuan tersebut diketahui oleh masyarakat sehingga masyarakat beranggapan bahwa polisi dalam menjalankan tugasnya telah melakukan pelanggaran.

Perilaku aparat kepolisian lalu lintas sangat berpengaruh terhadap citranya di mata masyarakat, hal ini menimbulkan dampak yang buruk bagi masyarakat terkait ketaatan hukum masyarakat. ${ }^{59}$ Kebanyakan masyarakat tidak takut melakukan pelanggaaran lalu lintas dengan tidak khawatir dirinya berkendara tanpa surat-surat kendaraan dan tidak begitu peduli untuk memenuhi kelengkapan kendaraannya karena masyarakat beranggapan jika tertangkap oleh polisi dapat diselesaikan dengan memberi uang sogokan. Bukannya membentuk karakter masyarakat

${ }^{58}$ Kunarto, Analisis Data Personil Dan Dimensi Permasalahannya Dalam Rangka Menunjang Operasional Kepolisian Republik Indonesia, Cipta Manunggal, Jakarta, 2004, hlm. 67.

59 Sudarso, Perilaku Berlalu Lintas Remaja di Perkotaan.Jurnal Masyarakat, Kebudayaan dan Politik, Th XIII. No 2, Jakarta, 2017, hlm. 45. yang taat hukum melainkan memberikan kesempatan terhadap masyarakat untuk melanggar hukum dan menjadikan masyarakat memandang rendah aparat kepolisian tanpa ada rasa segan padahal polisi merupakan penegak hukum dan panutan bagi masyarakat.

Menurut hasil wawancara dengan AKBP Juliani Prihatini, Kasatlantas Polrestabes Medan bahwa dalam melaksanakan tugas terkait pelanggaran lalu lintas dipengaruhi oleh masih adanya ketidakpedulian masyarakat khususnya orang tua dalam memberikan pengertian pada anak-anaknya untuk tidak melakukan pelanggaran lalu lintas, anggapannya bahwa masalah lalu lintas adalah tugas polisi lalu lintas semata sehingga masih banyak ditemukan pelanggaran lalu lintas yang dilakukan oleh anak-anak/pelajar. ${ }^{60}$

Perilaku-perilaku menyimpang yang di lakukan oleh aparat kepolisian juga merupakan faktor yang mempengaruhi terjadinya pelanggaran dalam penaggulangan tindak pidana lalu lintas. Perilaku menyimpang tersebut yaitu berupa pemanfaatan jabatan dan wewenangnya untuk menghasilkan sesuatu yang diinginkan. Hal-hal yang melanggar peraturan dan kode etik kepolisian mereka abaikan untuk mendapatkan keuntungan bagi mereka, disisi lain masyarakat sebagai korban merasa diuntungkan karena mereka diberikan pilihan atau lebih tepatnya solusi yang lebih mudah dibandingkan untuk mengikuti prosedur dan aturan yang berlaku yang mereka anggap berat dan membuang-buang waktu. ${ }^{61}$

Meskipun membawa sejumlah keuntungan, hal-hal yang seperti ini dapat

60 Hasil wawancara dengan AKBP Juliani Prihatini, Kasatlantas Polrestabes Medan, Tanggal 11 Maret 2019.

61 CST. Kansil dan Christine S.T. Kansil. Disiplin Berlalu Lintas di Jalan Raya, Rineka Cipta. Jakarta, 2005, hlm. 75 . 
Media Komunikasi dan Informasi Hukum dan Masyarakat

menimbulkan opini dan akan berkembang dikalangan masyarakat sehingga memberikan dampak yang negatif bagi citra kepolisian kedepan, bukannya menjadi bahan renungan bagi sebagian oknum aparat kepolisian sehingga aturan-aturan mengenai lalu lintas diterapkan sebagaimana mestinya sekaligus dapat mengubah opini dan tanggapantanggapan dari masyarakat tentang perilaku oknum aparat kepolisian, tetapi dalam realitanya ini menjadi suatu hal yang bisa dikatakan menarik dan membawa keuntungan yang besar bagi mereka. Sebaiknya setiap pelanggaran hukum yang terjadi dalam hal ini pelanggaran lalu lintas harus ditindaki oleh aparat penegak hukum sesuai dengan ketentuan yang berlaku dengan mengedepankan sikap profesional dan tentunya menjunjung tinggi hak asasi manusia. ${ }^{62}$

Penyalahgunaan wewenang polisi tidak terlepas dari kewenangan diskresi yang diberikan kepada polisi itu sendiri. Diskresi Kepolisian pada dasarnya merupakan kewenangan Kepolisian yang bersumber pada asas kewajiban umum Kepolisian (plichtmatigheids beginsel) yaitu suatu asas yang memberikan kewenangan kepada pejabat kepolisian untuk bertindak atau tidak bertindak menurut penilaiannya sendiri, dalam rangka kewajiban umumnya menjaga, memelihara ketertiban dan menjamin keamanan umum. ${ }^{63}$

Penyalahgunaan jabatan dan wewenang juga bisa dilakukan oleh polisi lalu lintas dalam menjalankan tugasnya. Di tengah masyarakat sudah bukan rahasia lagi bahwa polisi lalu lintas dalam melaksanakan tugas

\footnotetext{
62 Ibid., hlm. 78.

${ }^{63} \mathrm{HR}$. Abdussalam, Hukum Kepolisian Sebagai Hukum Positif dalam Disiplin Hukum. Restu Agung, Jakarta. 2009, hlm. 112.
}

dapat menyalahgunakan kewenangannya. Seperti misalnya meminta sejumlah uang tertentu kepada pelaku pelanggaran lalu lintas agar tidak ditilang, intimidasi terhadap tersangka pelaku pelanggaran lalu lintas dan masih banyak lagi. ${ }^{64}$

Menurut hasil wawancara dengan AKBP Juliani Prihatini, Kasatlantas Polrestabes Medan disebutkan bahwa kepercayaan masyarakat atas kinerja Polri belum sebagaimana yang diharapkan. Hal ini disebabkan adanya kesan yang kuat dalam masyarakat bahwa Polri lamban, tidak tanggap, diskriminatif dan kurang profesional dalam menangani laporan pengaduan masayrakat, ditambah lagi sikap perilaku anggota Polri yang belum santun dalam memberikan pelayanan. ${ }^{65}$

Polisi memang memiliki kewenangan untuk melakukan penegakan hukum berdasar undang-undang, tetapi mereka juga dibebani tanggung jawab untuk menjalankan kewenangannya secara benar dan bertanggung jawab. Para korban atau masyarakat lain secara hukum dapat meminta pertanggungjawaban aparat penagak hukum sebagai pribadi pejabat bila melakukan penyimpangan dalam proses penegakan hukum dan bertindak sewenang-wenang yang melanggar hak-hak asasi warga negara. ${ }^{66}$

Diskresi Kepolisian di Indonesia secara yuridis diatur pada Pasal 18 Undang-Undang Nomor 2 Tahun 2002 yaitu untuk kepentingan umum, pejabat Kepolisian Negara Republik Indonesia dalam melaksanakan tugas dan wewenangnya dapat bertindak menurut

\footnotetext{
64 Ibid., hlm. 114.

65 Hasil wawancara dengan AKBP Juliani Prihatini, Kasatlantas Polrestabes Medan, Tanggal 11 Maret 2019.

${ }^{66}$ CST. Kansil dan Christine S.T. Kansil, Op. Cit., hlm. 80 .
} 
Media Komunikasi dan Informasi Hukum dan Masyarakat

penilaiannya sendiri, hal tersebut mengandung maksud bahwa seorang anggota Polri yang melaksanakan tugasnnya di tengah tengah masyarakat seorang diri, harus mampu mengambil keputusaan berdasarkan penilaiannya sendiri apabila terjadi gangguan terhadap ketertiban dan keamanan umum atau bila timbul bahaya bagi ketertiban dan keamanan umum. ${ }^{67}$

Diskresi polisi dapat pula diartikan sebagai wewenang pejabat polisi untuk memilih bertindak atau tidak bertindak secara legal atau ilegal dalam menjalankan tugasnya. Diskresi membolehkan seorang polisi untuk memilih diantara berbagai peran (memelihara ketertiban, menegakkan hukum atau melindungi masyarakat) taktik (menegakkan undang-undang lalu lintas dengan berpatroli atau berjaga pada suatu tempat) ataupun tujuan (menilang pelanggar atau menasehatinya) dalam pelaksanaan tugasnya. ${ }^{68}$

Penggunaan diskresi oleh penegak hukum terlepas dari ada dan tidaknya intervensi dari atasan yaitu disuatu sisi berdampak positif terhadap penegakan hukum, meskipun dalam keadaan atau situasi tertentu demi kepentingan hukum harus melanggar hukum, tetapi disisi lain dapat menimbulkan masalah sendiri kepada Polri jika diskresi berupa kebijaksanaan merupakan suatu tindakan yang melanggar hukum atau jika kebijaksanaan tersebut terselubung sesuatu atau terdapat suatu kickback dari si pencari keadilan. ${ }^{69}$

67 Darmoko Y.W. dan Arya Putra N.K, Diskresi Hakim Sebuah Instrument Menegakkan Keadilan Substantif Dalam Perkara-Perkara Pidana, Alfabeta, Bandung, 2013, hlm. 89.

68 Ibid., hlm. 91.

69 Marwan Effendi, Diskresi, Penemuan Hukum, Korporasi dan Tax Amnesty Dalam Penegakan Hukum, Referensi, Jakarta, 2012, hlm.20.
Diskresi dalam hubungan antara warga negara dan penguasa ternyata menimbulkan masalah, sebabnya adalah bilamana alat penguasa bebas menetapkan atas dasar keinginannya sendiri hal-hal yang akan merugikan warga negara. $70 \mathrm{Di}$ dalam kekuasaan diskresi inilah polisi diberi kebebasan menurut pertimbangannya, apakah ia akan memeriksa seseorang, menahan, atau membebaskannya berdasarkan bukti-bukti dan aturan hukum yang telah diinterprestasikannya.

Keberadaan hak diskresi dengan memberi kewenangan polisi dalam mengambil keputusan di lapangan membuka peluang bagi polisi untuk melakukan negosiasi atau tawarmenawar dengan pelanggar lalu lintas untuk memberi imbalan kepada oknum petugas. ${ }^{71}$ Tindakan yang dilakukan oknum polisi tersebut menimbukan citra negatif bagi kepolisian. Kemerosotan citra Polri tersebut hampir merata di semua bidang tugas dan wewenangnya, termasuk dalam praktek penegakan hukum.

Munculnya kasus-kasus kriminal yang dilakukan oleh oknum polisi tersebut telah menimbulkan citra yang negatif terhadap Polri sekaligus menurunkan kepercayaan masyarakat terhadap cara-cara kerja yang dilakukan oleh Polri. Fenomena seperti itu tampaknya terpola juga dalam praktik-praktik penanggulangan tindak pidana pelanggaran lalu lintas. Secara khusus mengenai penanganan kasus pelanggaran lalu lintas jalan raya, bahwa denda damai dalam penanganan kasus pelanggaran lalu lintas telah menjadi kebiasaan.

Petugas cenderung bersepakat dengan pelanggar untuk membayar sejumlah

70 Roeslan Saleh, Dari Lembaran Kepustakaan Hukum Pidana. Sinar Grafika, Jakarta, 2012, hlm. 155.

71 Tabah Anton, Polri dan Penegakan Hukum di Indonesia, Majalah Unisia No. 22 Tahun XIV, Jakarta, 2004, hlm. 17. 
Media Komunikasi dan Informasi Hukum dan Masyarakat

uang di bawah ketentuan hukum agar pelanggarannya tidak diproses, dan uang damai tersebut tentu saja tidak masuk kas negara. Di pihak lain, citra polisi yang korup tersebut disebabkan pula oleh sikap khalayak yang terlanjur tidak mau repot, karena selalu dibayangi oleh prosedur hukum yang berbelibelit sehingga mendorong khalayak untuk lebih memilih jalan pintas dengan membayar denda damai. Cerita-cerita miring tentang sikap dan tindakan Polri yang demikian itu, dapat disimak dalam penanganan kasus-kasus tilang (bukti pelanggaran) kendaraan bermotor selama ini. 72

Beberapa faktor yang mempengaruhi penyalahgunaan wewenang kepolisian lalu lintas dalam menjalanjkan tugasnya adalah sebagai berikut:

1. Faktor perundang-undangan (substansi hukum).

Faktor

perundang-undangan

(substansi hukum) mempengaruhi pelaksanaan diskresi adalah agar setiap anggota kepolisian yang melaksanakan diskresi memiliki kepastian hukum dan dapat mempertanggung jawabkannya segala tindakan yang dilakukannya secara hukum. ${ }^{73}$

Tindakan diskresi yang ditempuh bertujuan untuk mendapatkan rasa adil bagi semua pihak dan tetap menjunjung tinggi Hak Asasi Manusia, juga terdapat pembatasanpembatasan dan pertanggung jawabannya, sekalipun hal tersebut tidak terdapat dalam KUHP akan tetapi pada hakekatnya untuk menjaga kepastian hukum dan ketertiban dalam masyarakat. ${ }^{74}$ Oleh sebab itu semua

\footnotetext{
72 Ibid.

${ }^{73}$ M. Faal. Penyaringan Perkara Pidana Oleh Polisi (Diskresi Kepolisian). Pradnya Paramita, Jakarta, 2011, hlm. 23.

74 F. Anton Susanto. Kepolisan dalam Upaya Penegakan Hukum di Indonesia. Rineka Cipta, Jakarta, 2004, hlm. 12
}

tindakan yang dilakukan penyidik harus berdasarkan hukum dan peraturan perundangundangan yang berlaku. Praktek kepolisian di Satuan Lalu Lintas Kepolisian Kota Besa Medan mengenyampingkan hukum atau menghentikannya atas pertimbanganpertimbangan atau atas permohonan pihak yang berkepentingan. ${ }^{75}$

2. Faktor penegak hukum (manusia).

Penegakan hukum bukanlah merupakan suatu kegiatan yang berdiri sendiri, melainkan mempunyai hubungan timabl balik yang erat dengan masyarakatnya. ${ }^{76}$ Hukum merupakan tumpuan harapan dan kepercayaan masyarakat untuk mengatur pergaulan hidup bersama. Hukum merupakan perwujudan atau manifestasi dari nilai-nilai kepercayaan. Oleh karena itu penegakan hukum diharapkan sebagai orang yang sepatutnya dipercaya dan menegakan wibawa hukum yang pada hakekatnya berarti menegakkan nilai-nilai kepercayaan di dalam masyarakat.

Kebijakan yang akan ditempuh akan mencakup bidang kegiatan penegakan hukum pertama-tama ditujukan guna meningkatkan ketertiban dan kepastian hukum dalam masyarakat. ${ }^{77}$ Dalam rangka ini maka akan dimantapkan penyempurnaan sistem koordinasi serta penyerasian tugas-tugas instansi aparat penegak hukum. hal ini dilakukan antara lain dengan menertibkan fungsi, tugas, kekuasaan dan wewenang lembaga-lembaga yang bertugas menegakkan hukum menurut profesi ruang lingkup masing-

75 Hasil wawancara dengan AKBP Juliani Prihatini, Kasatlantas Polrestabes Medan, Tanggal 11 Maret 2019.

76 Satjipto Rahardjo, Penegakan Hukum,
Publishing, Yogyakarta, 2005, hlm. 31. 77 M. Faal, Op. Cit., hlm. 25. 
Media Komunikasi dan Informasi Hukum dan Masyarakat

masing serta didasarkan atas sistem kerja sama yang baik.

Menurut Soerjono Soekanto menyebutkan bahwa: inti dan arti penegakan hukum terletak pada kegiatan menyerasikan hubungan nilai-nilai yang terjabarkan di dalam kaidah-kaidah yang mantap dan mengjewantah dan sikap tindak sebagai rangkaian penjabaran nilai tahap akhir, untuk menciptakan, memelihara dan mempertahankan kedamaian pergaulan hidup. ${ }^{78}$

Faktor penegak hukum yang mempengaruhi pelaksanaan diskresi kepolisian dalam penyelesaian perkara pelanggaran lalu lintas dapat diketahui berdasarkan kualitas dan kuantitas anggota kepolisian. Kualitas anggota kepolisian dilihat dari profesionalisme kerja polisi sebagai aparat penegak hukum, yang dituntut untuk melaksanakan tugas-tugasnya secara profesional terutama dalam mempergunakan wewenang diskresi yang dimilikinya dan Setiap polisi melakukan tugas berdasarkan sumpah jabatan dan berkewajiban untuk melaksanakan profesionalisme kerja secara maskimal. ${ }^{79}$

Faktor-faktor yang mempengaruhi penyalahgunaan wewenang kepolisian lalu lintas dalam menjalankan tugasnya adalah faktor manusia (iman), faktor pendidikan (pengetahuan tentang hukum) dan kesejahteraan dari anggota polisi itu sendiri (faktor ekonomi). ${ }^{80}$ Kuantitas anggota kepolisian dilihat dari idealnya jumlah anggota dalam melakukan pengaturan lalu lintas.

Faktor kuantitas anggota polisi yang terbatas ini dapat menghambat pelaksanaan

78 Soerjono Soekanto, Faktor-Faktor Yang Mempengaruhi Penegakan Hukum. Jakarta: Ghalia Indonesia, Jakarta, 2016, hlm.3.

${ }_{79}$ M. Faal, Op. Cit., hlm. 26.

$80 \mathrm{lbid}$. , hlm. 28. tugas penertiban lalu lintas dan jalan raya. Polisi harus benar-benar mampu menerapkan batasan-batasan dalam diskresi kepolisian, sehingga diskresi yang dilakukan demi kepentingan tugas-tugas kepolisian dan kepentingan umum, meskipun polisi telah diberikan kewenangan oleh undang-undang untuk mengambil tindakan lain tersebut tetap saja polisi harus bisa untuk mempertanggung jawabkan atas segala tindakan dan keputusan yang telah diambil dalam melaksanakan tugasnya. $^{81}$

3. Faktor masyarakat.

Faktor masyarakat yang dapat mempengaruhi pelaksanaan diskresi adalah kesadaran hukum yang dimiliki oleh masyarakat. Masyarkat menyadari bahwa pelanggaran lalu lintas adalah suatu kejadian di luar kehendak dan sama sekali tidak diinginkan sehinggga mereka menghendaki adanya perdamaian di luar pengadilan, sebab apabila hal tersebut diteruskan melalui jalur hukum maka permasalahan akan menjadi panjang.

Adanya kesadaran masyarakat ini maka ditempuhlah upaya perdamaian dan pihak kepolisian dengan kewenangan diskresi yang dimilikinya menjadi mediator dalam perdamaian tersebut. Dengan demikian penyelesaian perkara pidana lalu lintas dapat dilakukan di luar pengadilan yang menyangkut kecelakaan lalu lintas antara pihak-pihak yang terlibat tanpa melalui pengadilan. ${ }^{82}$

Proses penyelesaian tersebut dilakukan oleh para pihak sendiri karena masing-masing pihak sepakat untuk menyelesaikan tanpa melalui proses yang berbelit-belit dan memakan waktu yang lama,

\footnotetext{
${ }^{81}$ Ibid., hlm. 29

${ }^{82}$ F. Anton Susanto, Op. Cit., hlm 45
} 
Media Komunikasi dan Informasi Hukum dan Masyarakat

adapun hal ini terjadi karena pengadilan akan mempelajari bukti-bukti yang ada guna mencari kebenaran dan keadilan yang dapat diterima kedua belah pihak tanpa tekanan atau paksaan dari pihak manapun. ${ }^{83}$

4. Faktor kebudayaan.

Faktor budaya yang mempengaruhi pelaksanaan diskresi adalah nilai-nilai budaya di Indonesia yang mengedepankan prinsip kekeluargaan, musyawarah dan mufakat dalam menyelesaikan suatu permasalahan, sehingga dalam konteks kecelakaan lalu lintas, faktor budaya ini berpengaruh besar, di mana masyarakat menggunakan nilai-nilai kebudayaan berupa kekeluargaan, musyawarah dan mufakat dalam menyelesaikan perkara lalu lintas. Budaya yang sampai dengan saat ini dipegang teguh oleh masyarakat adalah penyelesaian masalah melalui musyawarah dan mufakat dalam rangka mencari perdamaian. ${ }^{84}$

5. Faktor ekonomi.

Faktor ekonomi dapat dilihat dari tingkat kesejahteraan anggota polisi lalu lintas yang masih belum terpenuhi. Penyalahgunaan wewenang yang dilakukan polisi lalu lintas secara umum karena motif ekonomi yang bermuara pada materi untuk tambahan penghasilan polisi tersebut.

6. Faktor disiplin.

Tingkat disiplin anggota polisi merupakan faktor yang sangat menentukan bagi terselenggaranya penegakan hukum yang tidak menyalahi wewenang yang dipikulnya. Penyalahgunaan wewenang polisi lalu lintas merupakan cermin dari rendahnya tingkat disiplin dari anggota polisi itu sendiri. ${ }^{85}$

\footnotetext{
${ }_{83} \mathrm{lbid} ., \mathrm{hlm} .46$.

84 Ibid., hlm. 47.

${ }^{85}$ M. Faal, Op. Cit., hlm. 30
}

\section{Sanksi Bagi Anggota Polisi Republik Indonesia yang Melakukan Tindak Pidana menurut Undang-Undang Nomor 2 Tahun 2002}

Salah satu kelompok yang menjalin suatu hubungan dengan polisi yaitu masyarakat (publik), polisi menjalin suatu pola hubungan yang istimewa yaitu polisi mempunyai kewajiban untuk melayani sedangkan disisi lain polisi melayani masyarakat dengan cara berlawanan dengan prinsip pelayanan yaitu mendisiplinkannya. Birokrasi dalam Polri merupakan birokrasi weberian, yaitu semakin tinggi jabatannya semakin besar kewenangan atau kekuasaannya. Semakin rendah hierarkinya semakin kecil pula wewenangnya. ${ }^{86}$

Anggota Polisi Republik Indonesia yang melakukan tindak pidana, dengan berlakunya Undang-Undang Nomor 2 Tahun 2002 tentang Kepolisian Republik Indonesia maka anggota Polisi tersebut dikenakan hukuman sebagaimana layaknya warga sipil lainnya yang melakukan tindak pidana. Hal tersebut diperjelas dalam Peraturan Pemerintah Nomor 3 Tahun 2003 Tentang Mekanisme Penanganan Anggota Polisi Republik Indonesia Yang Melakukan Tindak Pidana.

Anggota Polisi Republik Indonesia yang melakukan tindak pidana, maka penanganan proses penyidikan perkaranya di tangani oleh kesatuan reserse kriminal setelahnya diserahkan kepada Pelayanan Pengaduan Penegakan Displin (P3D) atau yang lebih di kenal dengan sebutan Propam, yang selanjutnya dari hasil penyidikan tersebut berkas perkaranya dilimpahkan ke kejaksaan untuk selanjutnya disidang di pengadilan

\footnotetext{
${ }^{86}$ Rahardi Pudi, Op.Cit, hlm. 11.
} 
Media Komunikasi dan Informasi Hukum dan Masyarakat

setempat dimana locus delicty perkara terjadi. Apabila telah dijatuhi vonis hukuman, maka bagi anggota Polisi Republik Indonesia tersebut mendapatkan sanksi yang sama pula dengan masyarakat sipil lainnya. ${ }^{87}$

Dasar hukum sanksi anggota Polisi Republik Indonesia yang melakukan tindak pidana sebagaimana yang diatur dalam beberapa Peraturan Perundang-Undangan adalah sebagai berikut:

1. Pasal 30 ayat (1) Undang-Undang Nomor 2 Tahun 2002 Tentang Kepolisian Republik Indonesia berbunyi: "Anggota Kepolisian Negara Republik Indonesia dapat di berhentikan dengan hormat atau tidak dengan hormat."

2. Pasal 11 (a) Peraturan Pemerintah Nomor 1 Tahun 2003 Tentang Pemberhentian anggota Kepolisian Republik Indonesia yang berbunyi: "Anggota Kepolisian Negara Republik Indonesia dapat deberhentikan dengan tidak hormat apabila melakukan tindak pidana".

3. Pasal 13 ayat (1) Peraturan Pemerintah Nomor 1 Tahun 2003 Tentang Pemberhentian Anggota Kepolisian Negara Republik Indonesia dapat diberhentikan dengan tidak hormat dari dinas Kepolisian Republik Indonesia karena melanggar sumpah/janji anggota Kepolisian Republik Indonesia, kode etik profesi Kepolisian Negara Republik Indonesia.

Anggota Kepolisian Negara Republik Indonesia pada dasarnya tunduk pada kekuasaan peradilan umum seperti halnya warga sipil pada umumnya. Demikian yang disebut dalam Pasal 29 ayat (1) UndangUndang Nomor 2 Tahun 2002 tentang

\footnotetext{
${ }^{87}$ HR. Abdussalam, Op. Cit., hlm. 72.
}

Kepolisian Negara Republik Indonesia. Hal ini menunjukkan bahwa anggota Kepolisian RI merupakan warga sipil dan bukan termasuk subjek hukum militer.

Anggota Polri karena profesinya juga tunduk pada Peraturan Disiplin dan Kode Etik Profesi yang diatur dalam Peraturan Pemerintah Nomor 2 Tahun 2003 tentang Peraturan Disiplin Anggota Kepolisian Negara Republik Indonesia. Sedangkan, kode etik kepolisian diatur dalam Perkapolri Nomor 14 Tahun 2011 tentang Kode Etik Profesi Kepolisian Negara Republik Indonesia.

Etika adalah ilmu pengetahuan tentang perilaku manusia yang terkait dengan norma dan nilai-nilai atau ukuran baik yang berlaku pada masyarakat. ${ }^{88}$ Sementara itu, dalam istilah Latin, ethos atau ethikos selalu disebut dengan mos, sehingga dari perkataan tersebut lahirlah moralitas atau yang sering diistilahkan dengan perkataan moral. Namun demikian, apabila dibandingkan dalam pemakaian yang lebih luas, perkataan etika dipandang sebagai lebih luas dari perkataan moral, sebab terkadang istilah moral sering dipergunakan hanya menerangkan sikap lahiriah seseorang yang biasa dinilai dari wujud tingkah laku atau perbuatan nyata. ${ }^{89}$

Pengertian kepolisian pada intinya adalah aparat penegak hukum yang bertanggung jawab atas ketertiban umum, keselamatan dan keamanan masyarakat. Jadi Etika Kepolisian adalah norma tentang perilaku polisi untuk dijadikan pedoman dalam mewujudkan pelaksanaan tugas yang baik bagi penegak hukum, ketertiban umum dan

${ }^{88}$ Suhrawardi K.Lubis, Etika Profesi Hukum, sinar Grafika, Jakarta, 2016, hlm. 9.

${ }^{89}$ Sumaryono, Etika Profesi Hukum, NormaNorma Bagi Penegak Hukum, Kanisius, Yogyakarta, 2015, hlm. 21. 
Media Komunikasi dan Informasi Hukum dan Masyarakat

keamanan masyarakat. ${ }^{90}$ Etika sebenarnya memperkuat hati nurani yang baik dan benar dari diri pribadi, sehingga mereka sungguhsungguh merasakan bahwa hidupnya, pengabdiannya, pelaksanaan tugasnya dan tingkah lakunya adalah berguna, bermanfaat bagi masyarakat, dan karenanya dia dihargai, diterima, bahkan ditempatkan secara terhormat di dalam masyarakatnya. Etika kepolisian dapat mengangkat martabat kepolisian di dalam masyarakat jika dilaksanakan dengan baik.

Etika kepolisian saat ini memang belum mentradisi seperti etika lainnya, walaupun usianya lebih tua. Hal itu disebabkan karena sejak awal etika kepolisian itu terus berkembang dan berubah-ubah, sehingga isi dan bentuk profesi kepolisian itu sendiri belum seragam, antara negara yang satu dengan yang lain. Aplikasi, para pemikir dan pimpinan kepolisian sering melupakan beberapa ciri atau karakter pelaku polisi atau sering disebut budaya polisi (police cultura) yang dominan pengaruhnya terhadap kegagalan tindakannya ${ }^{91}$ Kecenderungan itu antara lain:

1. Orientasi tindakan sering mengutamakan pencapaian hasil optimal (efektifitas), sehingga sering mengabaikan efisiensi.

2. Polisi diajar untuk selalu bersikap curiga, sehingga harus bertanya dengan detail. Sedangkan sikap curiga ini mengandung makna waspada dengan dasar pengertian etika.

3. Disatu pihak polisi dinilai tidak adil, tidak jujur, tidak professional, di pihak lain banyak petunjuk bahwa polisi harus mendukung dan menunjukkan solidaritas pada lingkungan.

4. Pragmatisme yang banyak mendatangkan keberhasilan, sering membuat polisi dan lalu melalaikan akar pragmatisme itu sendiri. ${ }^{92}$
Proses penyimpangan etika di Amerika Serikat, yang pada hakekatnya terjadi dimanamana, diawali dengan banyaknya penyimpangan etika kepolisian atau prilaku polisi yang tidak etis, berupa tindakan-tindakan kekerasan, penyimpangan berupa tindakan yang menyalahi prosedur, tindakan yang tidak melahirkan keadilan dan kebenaran dan lainlain. Hal itu mengakibatkan masyarakat sering memberi simpati pada orang-orang yang menjadi korban tindakan polisi itu, walaupun mereka berbuat jahat. ${ }^{93}$

Sikap antipati terhadap polisi itu meluas pada orang-orang yang diindikasi membantu polisi untuk mencelakakan sesama warga. Disana dikenal istilah fink (tukang lapor), stool pigeon yang kalau di Indonesia diistilahkan informan, orang yang diumpankan untuk menangkap penjahat, yang terburuk adalah chiken (pengecut), julukan ini diberikan kepada orang-orang yang menunjukkan penjahat bahkan kadang orang-orang yang tidak bersalah dilaporkan sebagai penjahat. Sebaliknya, orang yang dianggap pahlawan kalau dia diam, tidak melapor, membiarkan kejahatan terjadi atau tidak memberikan kesaksian, walaupun dirinya bahkan nyawanya jadi taruhan. Kenyatan-kenyataan itulah yang membuat renggang polisi dengan masyarakat. ${ }^{94}$

Pengembangan Etika Kepolisian dapat dilakukan, ditumbuhkan, dibangun dan dipupuk agar dapat subur dan berkembang dengan baik adalah dengan cara-cara sebagai berikut:

1. Membangun masyarakat. Mewujudkan masyarakat yang mampu berbuat etis tidaklah mudah, karena harus memperhitungkan segenap unsur pendukung eksistensinya yang berdimensi sangat luas. Dengan mengasumsikan

\footnotetext{
${ }^{93}$ HR. Abdussalam, Op. Cit., hlm. 81

94 lbid., hlm. 82
}

${ }^{91}$ Rahardi Pudi, Op.Cit, hlm. 17.

92 Ibid., hlm. 20. 
Media Komunikasi dan Informasi Hukum dan Masyarakat

bahwa terdapat banyak dimensi prilaku masyarakat yang baik dan mendukung etika kepolisian dengan baik, maka dari banyak dimensi itu yang paling signifikan bagi pelaksanaan tugas polisi adalah berupa dimensi hukum, kepatuhan mereka kepada hukum dan sikap menolak gangguan keamanan atau pelanggaran hukum. Dari hukum yang baik itulah, etika atau prilaku masyarakat yang terpuji dapat terbentuk, yang pada gilirannya akan mengembangkan aplikasi etika kepolisian.

2. Membentuk polisi yang baik Bibit-bibit atau calon polisi yang baik adalah dididik, dilatih, diperlengkapi dengan baik dan kesejahteraan yang memadai. Calon yang baik hanya dapat diperoleh dari masyarakat yang terdidik baik, persyaratan masuk berstandar tinggi, pengujian yang jujur dan fair (penuh keterbukaan), dan bakat yang memadai berdasarkan psikotes.

3. Membentuk pimpinan polisi yang baik Pada dasarnya, sama dan serupa dengan proses membentuk individu polisi yang baik di atas. Pimpinan yang berstatus perwira harus dituntut standar yang lebih tinggi. Semakin tinggi pangkatnya maka semakin tinggi pula standar persaratannya, khususnya unsur kepemimpinannya. ${ }^{95}$

Etika Kepolisian itu tidak mungkin dirumuskan secara universal semua dan berlaku sepanjang masa maka, rumusannya akan berbeda satu dengan yang lain. Namun suatu Kode Etik kepolisian yang baik adalah rumusan yang mengadung pokok pikiran sebagai berikut:

1. Mengangkat kedudukan profesi kepolisian dalam pandangan masyarakat dan untuk memperkuat kepercayaan masyarakat kepada kepolisian.

2. Mendorong semangat polisi agar lebih bertanggung jawab.

3. Mengembangkan dan memelihara dukungan dan kerjasama dari masyarakat pada tugas-tugas kepolisian.

4. Mengalang suasana kebersamaan internal kepolisian untuk menciptakan pelayanan yang baik bagi mayarakat.

5. Menciptakn kerjasama dan kordinasi yang harmonis dengan sesama aparat pemerintah agar mencapai keuntungan bersama (sinergi).

\footnotetext{
${ }^{95}$ Rahardi Pudi, Op.Cit, hlm. 89..
}

6. Menempatkan pelaksanaan tugas polisi sebagai profesi terhormat dan memandang sebagai sarana berharga dan terbaik untuk mengabdi pada masyarakat. ${ }^{96}$

Pokok pikiran ini dinilai sebagai citacita yang tinggi dan terhormat bagi kepolisian, dasar pola pemikiran yang diangap bersifat universal. ${ }^{97}$ Sehingga Internasional Association of Chief of Police (IACP) atau Asosiasi KepalaKepala Kepolisian Internasional yang selalu mengadakan pertemuan rutin setiap tahun di Amerika Serikat, menganggap masalah ini penting untuk dibahas dan disepakati untuk dijadikan pedoman perumusan Kode Etik Kepolisian, IACP, FBI (Federal Bureau of Investigation) dan The Peace Officers Association of The State of California Inc (Persatuan Petugas Keamanan California) menyepakati dijadikan pokok-pokok pikir pedoman, namun rumusan akhirnya disesuaikan dengan kondisi dan kebutuhan instansi kepolisian. ${ }^{98}$

Etika kepolisian yang benar, baik dan

kokoh, akan merupakan sarana untuk:

1. Mewujudkan kepercayaan diri dan kebanggan sebagai seorang polisi, yang kemudian dapat menjadi kebanggan bagi masyarakat.

2. Mencapai sukses penugasan.

3. Membina kebersamaan, kemitraan sebagai dasar membentuk partisipasi masyarakat.

4. Mewujudkan polisi yang professional, efektif, efesien dan modern, yang bersih dan berwibawa, dihargai dan dicintai masyarakat. 99

Etika Kepolisian merupakan suatu norma atau serangkaian aturan yang ditetapkan untuk membimbing petugas dalam menentukan, apakah tingkah laku pribadinya benar atau salah. Dengan memahami

\footnotetext{
${ }^{96}$ Ibid., hlm.91.

${ }^{97}$ Sadjijono, Op. Cit., hlm.53

${ }_{98}^{98}$ lbid.

99 lbid, hlm. 55.
} 
Media Komunikasi dan Informasi Hukum dan Masyarakat

pengertian dasar Etika Kepolisian, yang menjadi akar dan pedoman, yang menopang bentuk perilaku ideal yang kokoh dari polisi dalam melaksanakan pengabdiannya maka, akan membuat mereka teguh dalam pendiriannya, sehingga mereka dapat mengambil sikap yang tepat dalam setiap tindakannya.

Sikap itu berpangkal dari integritas yang mendalam di sanubari dan hati nuraninya. Itulah dasar dari moralitas etika kepolisian yang bersifat hakiki. Tanpa memahami dasar itu seorang polisi akan dapat goyah apabila menghadapi problema-problema yang dijumpai dalam penugasan. Sikap goyah itu akan mendorong mereka untuk berperilaku menyimpang dari etika kepolisian yang seharusnya mereka tegakkan. Pemahaman yang tidak sempurna akan membuat mereka patuh hanya kalau ada pengawasan saja. Hal itu dapat diartikan sebagi sikap yang serba goyah, sikap yang tidak stabil, sikap yang tidak mantap bahkan pelecehan terhadap Etika Kepolisian.

Etika Kepolisian yang diaplikasikan dengan baik dan benar akan membantu polisi dalam pemecahan masalahnya sehari-hari. Polisi secara tepat dapat menentukan apakah tindakan itu baik atau tidak baik dalam mengemban tugas mereka. Apakah harus menerima uang imbalan atas hasil karyanya atau harus menolaknya, secara tegas yang sudah disebut dalam sumpah jabatan. Sikap professional dan keteladanan akan segera terlihat dan terasa pada saat dia menentukan tindakannya. ${ }^{100}$

Adanya kode etik, pengembangan akan lebih terarah, akan terkoordinasi, dan 2011, hlm. 17.
${ }^{100}$ Momo Kelana, Hukum Kepolisian. PTIK. Jakarta, mendatangkan mamfaat serta dukungan yang maksimal dari masyarakat. Semua kode etik intinya merupakan aturan-aturan dan peraturan yang diendapkan dari cita-cita dan kegiatan untuk mewujudkan cita-cita. ${ }^{101}$

Polri harus menjunjung tinggi kehormatan dan martabat Negara, Pemerintah, dan Kepolisian Negara Republik Indonesia (Pasal 3 huruf c Peraturan Pemerintah Nomor 2 Tahun 2003) dan menaati peraturan perundang-undangan yang berlaku, baik yang berhubungan dengan tugas kedinasan maupun yang berlaku secara umum (Pasal 3 huruf $g$ Peraturan Pemerintah Nomor 2 Tahun 2003). Dengan melakukan tindak pidana, ini berarti Polri melanggar peraturan disiplin.

Pelanggaran peraturan disiplin adalah ucapan, tulisan, atau perbuatan anggota Kepolisian Negara Republik Indonesia yang melanggar peraturan disiplin (Pasal 1 angka 4 Peraturan Pemerintah Nomor 2 Tahun 2003). Anggota Kepolisian Negara Republik Indonesia yang ternyata melakukan pelanggaran Peraturan Disiplin Anggota Kepolisian Negara Republik Indonesia dijatuhi sanksi berupa tindakan disiplin dan/atau hukuman disiplin (Pasal 7 Peraturan Pemerintah Nomor 2 Tahun 2003).

Tindakan disiplin berupa teguran lisan dan/atau tindakan fisik (Pasal 8 ayat (1) Peraturan Pemerintah Nomor 2 Tahun 2003). Tindakan disiplin tersebut tidak menghapus kewenangan Atasan yang berhak menghukum (Ankum) untuk menjatuhkan hukuman disiplin.

Pasal 9 Peraturan Pemerintah Nomor 2 Tahun 2003 menyebutkan hukuman disiplin tersebut berupa:

a. Teguran tertulis;
101 Ibid., hlm. 17 
Media Komunikasi dan Informasi Hukum dan Masyarakat

b. Penundaan mengikuti pendidikan paling lama 1 (satu) tahun;

c. Menundaan kenaikan gaji berkala;

d. Penundaan kenaikan pangkat untuk paling lama 1 (satu) tahun;

e. Mutasi yang bersifat demosi;

f. Pembebasan dari jabatan;

g. Penempatan dalam tempat khusus paling lama 21 (dua puluh satu) hari.

Penjatuhan hukuman disiplin untuk pelanggaran disiplin Polri, diputuskan dalam sidang disiplin. Polisi yang melakukan tindak pidana misalkan pemerkosaan, penganiyaan, dan pembunuhan (penembakan) terhadap warga sipil, maka polisi tersebut tidak hanya telah melakukan tindak pidana, tetapi juga telah melanggar disiplin dan kode etik profesi polisi. ${ }^{102}$

Proses hukum oknum polisi yang melakukan tindak pidana, pelanggaran terhadap aturan disiplin dan kode etik akan diperiksa dan bila terbukti akan dijatuhi sanksi. Penjatuhan sanksi disiplin serta sanksi atas pelanggaran kode etik tidak menghapus tuntutan pidana terhadap anggota polisi yang bersangkutan. Oleh karena itu, polisi yang melakukan tindak pidana tersebut tetap akan diproses secara pidana walaupun telah menjalani sanksi disiplin dan sanksi pelanggaran kode etik.

Proses peradilan pidana bagi anggota Kepolisian Negara Republik Indonesia secara umum dilakukan menurut hukum acara yang berlaku di lingkungan peradilan umum. Hal ini diatur dalam Pasal 2 Peraturan Pemerintah Nomor 3 Tahun 2003 tentang Pelaksanaan Teknis Institusional Peradilan Umum Bagi Anggota Kepolisian Negara Republik Indonesia.

${ }^{102}$ Adrianus Meliala, Op. Cit., hlm. 71.
Sidang Komisi Kode Etik Polri (sidang KKEP) adalah sidang untuk memeriksa dan memutus perkara pelanggaran Kode Etik Profesi Polri (KEPP) yang dilakukan oleh anggota Polri sebagaimana disebut dalam Pasal 1 angka 7 Perkapolri Nomor 14 Tahun 2011 tentang Kode Etik Profesi Kepolisian Negara Republik Indonesia. Selain itu Sidang KEPP juga dilakukan terhadap pelanggaran Pasal 13 Peraturan Pemerintah Nomor 2 Tahun 2003.

Pasal 13 Peraturan Pemerintah Nomor 2 Tahun 2003 : Anggota Kepolisian Negara Republik Indonesia yang dijatuhi hukuman disiplin lebih dari 3 (tiga) kali dan dianggap tidak patut lagi dipertahankan statusnya sebagai anggota Kepolisian Negara Republik Indonesia, dapat diberhentikan dengan hormat atau tidak dengan hormat dari dinas Kepolisian Negara Republik Indonesia melalui Sidang Komisi Kode Etik Profesi Kepolisian Negara Republik Indonesia.

Terkait sidang disiplin, tidak ada peraturan yang secara eksplisit menentukan manakah yang terlebih dahulu dilakukan, sidang disiplin atau sidang pada peradilan umum. Hal yang diatur hanya bahwa sidang disiplin dilaksanakan paling lambat 30 (tiga puluh) hari setelah Ankum menerima berkas Daftar Pemeriksaan Pendahuluan (DPP) pelanggaran disiplin dari provos atau pejabat lain yang ditunjuk oleh Ankum (Pasal 23 Peraturan Pemerintah Nomor 2 Tahun 2003 dan Pasal 19 ayat (1) Keputusan Kepala Kepolisian Negara Republik Indonesia No. Pol.: Kep/44/IX/2004 tentang Tata Cara Sidang Disiplin Bagi Anggota Kepolisian Negara Republik Indonesia.

Menurut Pasal 22 ayat (1) Perkapolri Nomor 14 Tahun 2011 tentang Kode Etik Profesi Kepolisian Negara Republik Indonesia 
Media Komunikasi dan Informasi Hukum dan Masyarakat

bahwa sanksi administratif berupa rekomendasi PTDH dikenakan melalui Sidang KEPP terhadap:

a. Pelanggar yang dengan sengaja melakukan tindak pidana dengan ancaman hukuman pidana penjara 4 (empat) tahun atau lebih dan telah diputus oleh pengadilan yang berkekuatan hukum tetap.

b. Pelanggar yang melakukan pelanggaran sebagaimana dimaksud dalam pasal 21 ayat (3) huruf e, huruf $g$, huruf $h$, dan huruf i.

\section{KESIMPULAN DAN SARAN}

\section{A. Kesimpulan}

Berdasarkan uraian pada bab sebelumnya, maka dalam tesis ini dapat disimpulan sebagai berikut :

1. Faktor penyebab penyalahgunaan wewenang yang dilakukan oleh polisi lalu lintas di Polrestabes Medan adalah faktor ekonomi yaitu kurangnya penghasilan yang diperoleh seorang aparat kepolisian yang tidak sebanding dengan tingginya kebutuhan biaya hidup sehingga berpengaruh pada perilaku untuk mencari penghasilan lebih. Selain faktor ekonomi, kedekatan emosional dengan aparat kepolisian juga mempengaruhi terjadinya pelanggaran dalam penaggulangan lalu lintas. Kedekatan emosional dalam hal ini meliputi persamaan asal daerah, adanya hubungan keluarga, kesamaan profesi, serta hal-hal lainnya yang menjadikan mereka memiliki latar belakang yang sama dalam suatu hal tertentu. Perilaku menyimpang yang dilakukan oleh aparat kepolisian juga merupakan faktor yang mempengaruhi terjadinya pelanggaran dalam penaggulangan tindak pidana lalu lintas. Perilaku menyimpang tersebut yaitu berupa pemanfaatan jabatan dan wewenangnya untuk menghasilkan sesuatu yang diinginkan.

2. Penindakan yang dilakukan Propam terhadap polisi lalu lintas yang melampaui kewenangannya dalam menjalankan tugas di Polrestabes Medan adalah dengan memberikan sanksi atas pelanggaran disiplin terhadap anggota Polri. Sanksi pelanggaran disiplin berupa teguran tertulis, penundaan mengikuti pendidikan, penundaan gaji berkala, penundaan kenaikan pangkat, mutasi yang bersifat demosi dan penempatan dalam tempat khusus. Penyelesaian pelanggaran disiplin anggota Polri diselesaikan dengan penjatuhan sanksi hukuman disiplin melalui sidang disiplin.

\section{B. Saran}

1. Agar dalam melaksanakan tugas-tugasnya polisi diharapkan lebih berinteraksi dan bersosialisasi dengan masyarakat dalam menyelesaikan pelanggaran-pelanggaran lalu lintas yang dilakukan oleh masyarakat.

2. Diharapakan kepada aparat kepolisian dal hal ini polisi lalu lintas memahami isi dari peraturan perundang-undangan sehingga dapat menjalanakan tugas-tugas dan kewajibannya dengan baik.

3. Agar Polisi selain menjunjung tingggi sikap profesionalisme dalam menjalankan tugas polisi diharapkan bersikap humanis dan menjadi contoh teladan bagi masyarakat dalam berlalu lintas. 
Media Komunikasi dan Informasi Hukum dan Masyarakat

\section{Daftar Bacaan}

\section{A. Buku}

Abdussalam, HR. Hukum Kepolisian Sebagai Hukum Positif dalam Disiplin Hukum. Restu Agung, Jakarta. 2009.

Ali, Zainuddin, Metode Penelitian Hukum, Sinar Grafika, Jakarta, 2009.

Amiruddin dan Zainal Asikin, Pengantar Metode Penelitian Hukum, Raja Grafindo Persada, Jakarta, 2004.

Ashshofa, Burhan, Metodologi Penelitian Hukum, Rineka Cipta, Jakarta, 2006.

Arief, Barda Nawawi, Bunga Rampai Kebijakan Hukum Pidana. Kencana Prenada Media Group, Jakarta, 2008

Atmasasmita, Romli, Sistem Peradilan Pidana(Criminal Justice System) Perspektif Eksistensialisme Dan Abolisionalisme, Bina Cipta, Jakarta, 2006.

Darmanto, Andi, Tugas dan Kewenangan Polri (Satuan Lalulintas), Mizan, Bandung, 2017

Djamin, Awaloedin, Sejarah dan Perkembangan Kepolisian di Indonesia. Yayasan Brata Bhakti Polri, Jakarta, 2007.

Effendi, Marwan, Diskresi, Penemuan Hukum, Korporasi dan Tax Amnesty Dalam Penegakan Hukum, Referensi, Jakarta, 2012.

Faal. M. Penyaringan Perkara Pidana Oleh Polisi (Diskresi Kepolisian). Pradnya Paramita, Jakarta, 2011

Fajar ND, Mukti dan Yulianto, Dualisme Penelitian Hukum: Normatif dan Empiris, Pustaka Pelajar, Yogyakarta, 2010.

Hadi, Sutrisno, Metodologi Riset, Andi Offset, Yogyakarta, 2009.

Hariandja, Disiplin Berlalu Lintas di Jalan Raya, Airlangga, Jakarta, 2012.

Ilham, Bisri, Sistem Hukum Indonesia, Grafindo Persada, Jakarta, 2004.

Kansil, C.S.T, Hukum Tata Negara Rapublik Indonesia, Rineka Cipta, Jakarta, 2000.

-; Pengantar Ilmu Hukum dan Tata Hukum Indonesia, Balai Pustaka, Jakarta, 2002.
Kansil, CST. dan Christine S.T. Kansil. Disiplin Berlalu Lintas di Jalan Raya, Rineka Cipta. Jakarta, 2005.

Kelana, Momo, Hukum Kepolisian. PTIK. Jakarta, 2011,

Kunarto, Perilaku Organisasi Polri, Cipta Manunggal, Jakarta, 2001.

Analisis Data Personil Dan Dimensi Permasalahannya Dalam Rangka Menunjang Operasional Kepolisian Republik Indonesia, Cipta Manunggal, Jakarta, 2004

Kusumaatmaja, Mochtar, Konsep Hukum Dalam Pembangunan, Alumni, Bandung, 2002.

Lubis, M. Solly, Filsafat IImu dan Penelitian, Mandar Maju, Bandung, 2004.

Lubis, Suhrawardi K. Etika Profesi Hukum, sinar Grafika, Jakarta, 2016

Mahmud, Peter, Penelitian Hukum, Edisi Pertama Cetakan keenam, Kencana Prenada Media Group, Jakarta, 2011.

Manan, Bagir, Pertumbuhan dan Perkembangan Konstitusi Suatu Negara, Mandar Maju, Bandung, 2005.

Meliala, Adrianus, Problema Reformasi Polri, Trio Repro, Jakarta, 2002.

Moleong, Lexy J, Metodologi Penelitian Kualitatif, Remaja Rosdakarya, Bandung, 2003.

Mulyadi, Mahmud dan Andi Sujendral. 2011. Community Policing: Diskresi Dalam Pemolisian Yang Demokratis. PT Sofmedia, Jakarta, 2011.

Poerwadarminta, WJS, Kamus Umum Bahasa Indonesia, Balai Pustaka, Jakarta, 2008.

Pudi, Rahardi, Hukum Kepolisian Kemandirian Profesionalisme dan Reformasi Polri, Laksbang Grafika, Surabaya, 2014.

Rahardjo, Satjipto, Penegakan Hukum, Publishing, Yogyakarta, 2005

Rasjidi, Lili, Hukum Sebagai Suatu Sistem, Mandar Maju, Bandung, 2003.

Reksodiputro, Mardjono, Sistem Peradilan Pidana Indonesia (Melihat Kepada Kejahatan Dan Penegakan Hukum Dalam Batas-Batas Toleransi), Fakultas Hukum Unversitas Indonesia, 2003. 
Media Komunikasi dan Informasi Hukum dan Masyarakat

Rianto, Budi, Polri dan Aplikasi E-Government, Putra Media Nusantara, Surabaya, 2012.

Sadjijono, Hukum Kepolisian Perspektif Kedudukan dan Hubungan Dalam Hukum Administrasi, LaskBang PRESSindo, Yogyakarta, 2006.

Saleh, Roeslan, Dari Lembaran Kepustakaan Hukum Pidana. Sinar Grafika, Jakarta, 2012

Soekanto, Soerjono, Pengantar Penelitian Hukum, UI Press, Jakarta, 2006.

---------; Faktor-Faktor Yang Mempengaruhi Penegakan Hukum, Raja Grafindo Persada, Jakarta, 2004.

Soekanto, Soerjono dan Sri Mamudji, Penelitian Hukum Normatif: Suatu Tinjauan Singkat, Raja Grafindo Persada, Jakarta, 2013.

Soekanto, Soerjono, Faktor-Faktor Yang Mempengaruhi Penegakan Hukum. Jakarta: Ghalia Indonesia, Jakarta, 2016

Sudikno dan Pitlo, Bab-Bab Tentang Penemuan Hukum, Citra Aditya Bakti, Bandung, 2003.

Sujata, Antoinius, Reformasi dalam Penegakan Hukum, Djambatan, Jakarta, 2014

Sumaryono, Etika Profesi Hukum, NormaNorma Bagi Penegak Hukum, Kanisius, Yogyakarta, 2015.

Suroso, Tugas dan Wewenang Polisi Lalu Lintas Dalam Praktik Penegakan Hukum Pidana, Ghalia Indonesia, Jakarta, 2015.

Susanto. F. Anton, Kepolisan dalam Upaya Penegakan Hukum di Indonesia. Rineka Cipta, Jakarta, 2004

Tabah, Anton, Membangun Polri yang Kuat, Sumberseu Lestari, Jakarta, 2008.

Tedjosaputro, Liliana, Etika Profesi Notaris Dalam Penegakan Hukum Pidana, Bigraf Publishing, Yogyakarta, 2005.

Waluyo, Bambang, Implementasi Kekuasaan Kehakiman Rl, Sinar Grafika, Jakarta, 2001.

Y.W. Darmoko dan Arya Putra N.K, Diskresi Hakim Sebuah Instrument Menegakkan Keadilan Substantif Dalam PerkaraPerkara Pidana, Alfabeta, Bandung, 2013.

\section{B. Peraturan Perundang-Undangan}

UUD 1945 Hasil Amandemen dan Proses Amandemen UUD 1945 secara lengkap (pertama 2009-keempat 2002), Sinar Grafika, Jakarta, 2002.

Undang-Undang Nomor 2 Tahun 2002 Tentang Kepolisian Negara Republik Indonesia.

Peraturan Pemerintah Nomor 1 Tahun 2003 Tentang Pemberhentian Anggota Kepolisian Negara Republik Indonesia.

Keputusan Kapolri No. Pol: KEP/01/ VII/2003 Tentang Naskah Kode Etik Profesi Kepolisian Negara Republik Indonesia.

Peraturan Kepala Kepolisian Negara Republik Indonesia Nomor 14 Tahun 2011 Tentang Kode Etik Profesi Kepolisian Negara Republik Indonesia.

\section{Internet/Karya IImiah/Jurnal.}

Abni, Hasnia, "upaya penal dan non penal", melalui http://Jurnal.com, diakses Senin, 15 Maret 2019 Pukul 20.00 wib.

Agus Subagyo, "Penegakan Etika Profesi dan Peraturan Disiplin Anggota Polri", melalui https://wordpress.com, diakses pada Jumat, 30 November 2018.

Djisman, "upaya penanggulangan kejahatan", melalui https://www.suduthukum.com, diakses 15 Maret 2019 Pukul 20.00 wib.

Firman, "Diskresi Polisi dan Permasalahannya", melalui http://www. Indonesia policewatch.com/, diakses pada Jumat, 30 November 2018.

Haryani. Trie, "Kekerasan Oleh Polisi, mengapa Masih Terjadi", melalui http:///kekerasan-oleh-polisi-mengapamasih.html, diakses pada Jumat, 30 November 2018.

Sudarso, Perilaku Berlalu Lintas Remaja di Perkotaan.Jurnal Masyarakat, Kebudayaan dan Politik, Th XIII. No 2, Jakarta, 2017.

Tabah, Anton, Polri dan Penegakan Hukum di Indonesia, Majalah Unisia No. 22 Tahun XIV, Jakarta, 2004 